EISSN: 2706-7955 ISSN: 2077-4605

DOI: 10.36632/mejar/2021.10.1.12

Journal homepage: www.curresweb.com

Pages: 207-226

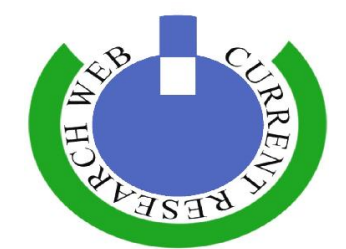

\title{
Effect of Potassium Levels as Soil Application and Foliar Spray with Silicon and Boron on Yield and Root Quality of Sugar Beet under Clay Soil
}

Samia M.S. El-Kalawy

Soils, Water and Environ. Res. Inst., Agric. Res. Centre., Giza, Egypt

Received: 10 December 2020 Accepted: 05 February 2021 Published: 20 February 2021

\begin{abstract}
A field experiment was carried out at El-Gemmeiza Agric. Res. Station,El Gharbeya Governorate, Egypt during the two successive winter seasons of 2016/2017 and 2017/2018. This investigation was aimed to study the effect of potassium levels $\left(0,12,18\right.$ and $24 \mathrm{~kg} \mathrm{~K}_{2} \mathrm{O} /$ fad.) and foliar spray with silicon in the form of potassium silicate $(200 \mathrm{ppm} \mathrm{Si})$ and boron in the form of boric acid at $250 \mathrm{ppm}$ B four times at $60,80,100$ and 120 days after sowing on growth, plant chemical constituents yield and root quality of sugar beet cv Oskar poly grown in clay soil conditions. The obtained results indicated that, the interaction between fertilizing sugar beet with potassium at $24 \mathrm{~kg} \mathrm{~K}_{2} \mathrm{O} / \mathrm{fad}$. In the form potassium sulphate and spraying with silicon at $200 \mathrm{ppm}$ gave the highest values of plant height, dry weight of shoots, roots and total dry weight/ plant, highest concentrations of chlorophyll $\mathrm{a}, \mathrm{b}$ and total $(\mathrm{a}+\mathrm{b})$ in leaf tissues, highest contents of potassium in shoots and roots and silicon in shoots, root diameter, average root weight, yield of top and total yield of roots /fad. as well as higher available potassium, silicon and boron in the soil after harvesting plants. Moreover, the interaction between potassium at 24 $\mathrm{kg} \mathrm{K}_{2} \mathrm{O} / \mathrm{fad}$. and spraying with boron at $250 \mathrm{ppm}$ gave the highest concentration of boron in the shoots, sucrose contents in juice of roots, juice purity, total yield of sugars /fed. No significant differences between boron and Si spraying on yield of sugars/fed. in both seasons. Whereas, the interaction between potassium at $12 \mathrm{kgK}_{2} \mathrm{O} / \mathrm{fad}$. and spraying with silicon at $200 \mathrm{ppm}$ significantly increased $\propto$ amino nitrogen in roots, while unfertilized and unsprayed plants recorded the highest contents on sodium in roots in both seasons. Impurity (\%) and sugar lost to molasses (\%) had no significant affected by the interaction between potassium levels and foliar spray treatments in both seasons.
\end{abstract}

Keywords: Sugar beet, potassium, silicon, boron, yield, quality, purity.

\section{Introduction}

Sugar is considered a strategic good that is an inexpensive source of energy, and it is produced by two main crop Species, i.e., sugarcane and sugar beet (Beta vulgaris L.). Sugar beet is the second most vital sugar crops after sugarcane. Sugar beet has become the main source of sugar in Egypt. In Egypt, the total production of sugar from sugar beet reached $56.61 \%$ (1.27 million tons), while the production of sugarcane constituted 43.39\% (0.931 million tons) (Sayed and Omar 2018).

Potassium $(\mathrm{K})$ is an essential element for plant growth with respect to its physiological and biochemical functions. It is necessary for activating starch synthetase enzyme (Fathy et al., 2009). Also, $\mathrm{K}$ plays an essential role in enzyme activation, protein synthesis, photosynthesis, osmoregulation, stomatal movement, energy transfer, phloem transport, cation-anion balance, and stress resistance (Wang et al., 2013).

Increasing potassium fertilizer for sugar beet caused a significant increase in growth, productivity and root quality (Fathy et al. 2009, Abo Shady et al. 2010, Mahdi et al. 2012, Mehrandish et al. 2013, Awad et al. 2013, Salami and Saadat, 2013, Neseim et al. 2014, Hamad, et al. 2015, Merwad, 2015, Mubarak et al. 2016, Salama et al., 2019 and Aksu and Altay, 2020).

Corresponding Author: Samia M.S. El-Kalawy, Soils, Water and Environ. Res. Inst., Agric. Res. Centre., Giza, Egypt. E-mail: samiaelkalawy342@gmail.com 
Silicon application is a novel idea of fertilization. Its favourable effect on many plant species growth and development was found by some researchers (Yamaji et al., 2008). However, the role of silicon in crops is not particularly well understood (Casey et al., 2003). Silicon plays a very important role in the reduction of the plants vulnerability to biotic and abiotic environmental stress (Sacała, 2009). Potassium silicate increases the plants' resistance to pathogens and pests (Cai et al., 2009). One of the most important beneficial effects of silicon on plant growth is related to increased resistance under water stress conditions (Ma et al., 2006). Sugar beet is one of seven plant species that are classified as silicon bio-accumulators (Guntzer et al., 2012).

Many authors showed significant enhancing growth, yield and best quality with spraying silicon on sugar beet (Artyszak et al. 2014, Abd El-hady, and Bondok, 2017, Ibrahim et al. 2017, Ali et al. 2019, El-Shabrawy and Abd Rabboh, 2020). Other authors showed that spraying silicon recorded the best results for growth, yield and quality of different crops (Abd- All, et al. 2017 on sweet potato, Sayed et al., 2018 on globe artichoke, Abd El-Aall et al.,2019 on taro Abdel-Latif et al., 2019 on garlic and Abuzeed et al., 2019 on taro).

Boron (B) is essentially trace element for the physiological function of higher plants. B deficiency can cause nutritional disorders that negatively affect plant metabolism and growth B. is by far the most important of the trace elements needed by sugar beet to avoid yield and quality of roots depresses (Cooke and Scott, 1993). Also, B promotes vital functions in sugar beet, such as maintaining the balance between sugar and starch and K? transport (Camacho-Cristo'bal and Gonza'lez-Fontes 2007).

Spraying sugar beet during growing season with boron had significant effect on growth, yield of roots, quality and improved the percentages of sugar (Kristek et al. 2006, Abido 2012, Abd El-Azez 2014, Dewdar et al. 2015, Masri and Hamza 2015, El-Sherief et al. 2016, Enan et al. 2016, Aly et al. 2017, Nemeata Alla, 2017, Dewdar et al. 2018, Abdel-Nasser and Ben-Abdalla, 2019, Rehab et al. 2019, Kandil et al. 2020 and Sarhan et al., 2020).

Therefore, this work aimed to study the effect of potassium levels as soil application and foliar spray with silicon and boron on yield and root quality of sugar beet under the clayey soil conditions.

\section{Materials and Methods}

A field experiment was carried out at El-Gemmeiza Agric. Res. Station, El Gharbeya Governorate, Egypt (longitude $317^{\circ} \mathrm{E}$ and latitude $3043^{\circ} \mathrm{N}$ ) during the two successive winter seasons of 2016/2017 and 2017/2018. This investigation was aimed to study the effect of potassium soil application levels and foliar spray with silicon and boron on growth, plant chemical constituents, root yield and root quality of sugar beet cv Oskar poly grown in clayey soil conditions. Some physical and chemical properties of the experimental soil determined according to Balck et al. (1981) and shown in Table 1.

Table 1: Some soil physical and chemical properties of the experimental sites during 2016/2017 and 2017/2018 seasons

\begin{tabular}{lcc}
\hline Parameter & \multicolumn{2}{c}{ Value } \\
\hline Physical properties & $\mathbf{2 0 1 7}$ & $\mathbf{2 0 1 8}$ \\
\hline Corse sand (\%) & 1.91 & 1.92 \\
Fine sand (\%) & 14.37 & 15.37 \\
Silt (\%) & 40.11 & 41.01 \\
Clay (\%) & 43.61 & 42.0 \\
Textural class & clayey loam & clayey loam \\
\hline Chemical properties & & \\
\hline $\mathrm{EC} \mathrm{dSm}$ ( soil past extract ) & 2.21 & 2.32 \\
$\mathrm{pH}(1: 2.5$ soil : water suspension) & 8.1 & 7.98 \\
$\mathrm{CaCO}_{3}(\%)$ & 2.7 & 2.4 \\
Organic matter (\%) & 1.94 & 1.79 \\
Available nitrogen (ppm) & 32.0 & 29 \\
Available phosphorus (ppm) & 7.9 & 8.2 \\
Available potassium (ppm) & 411 & 398 \\
Available boron (ppm) & 1.19 & 1.22 \\
Available silicon (ppm) & 0.002 & 0.003 \\
\hline
\end{tabular}


This experiment was included 12 treatments which were the combinations between four levels of potassium $\left(0,16,18\right.$ and $24 \mathrm{~kg} \mathrm{~K}_{2} \mathrm{O} / \mathrm{fad}$.) and three foliar spray treatments (unsprayed, silicon at 200 ppm Si and boron at $250 \mathrm{ppm} \mathrm{B.} \mathrm{These} \mathrm{treatments} \mathrm{were} \mathrm{arranged} \mathrm{in} \mathrm{a} \mathrm{split} \mathrm{plot} \mathrm{in} \mathrm{a} \mathrm{complete} \mathrm{block}$ design with three replications. Potassium levels were randomly distributed in the main plot, while foliar spray treatments were randomly arranged in the sub plots.

The experimental unit area was $9.6 \mathrm{~m}^{2}$. It contains four ridges with $4 \mathrm{~m}$ length each and $60 \mathrm{~cm}$ distance between each two ridges. One ridge was used for taking samples to measure the morphological and physiological traits and the other ridges were used for yield determinations.

The seeds were sown in the first week of November in both growing seasons. Sugar beet was hand sown 3-5 balls (seeds)/hill using dry sowing method on one side of the ridge in hills $20 \mathrm{~cm}$ apart. Plants were thinned to one plant/hill at the age of 30 days from sowing.

Phosphorus fertilizer at the rate of $30 \mathrm{~kg} \mathrm{P}_{2} \mathrm{O}_{5} / \mathrm{fad}$. in the form of calcium super phosphate $(15.5 \%$ $\mathrm{P}_{2} \mathrm{O}_{5}$ ) was added during land preparation. Potassium fertilizer with the mentioned levels was applied after thinning in one dose ( 30 days after sowing). Also, the nitrogen fertilizer in the form of urea (46 $\% \mathrm{~N})$ with the recommended rate $(80 \mathrm{~kg} \mathrm{~N} / \mathrm{fed})$ was applied as split into two equal doses, half one before the second irrigation after thinning and the other one after 15 days later before the third irrigation. Other cultural practices were done as recommended.

The plants sprayed with silicon and boron four times; i. e., 60, 80, 100 and 120 days after sowing in both seasons. Each plot received two liter solutions of different spraying treatments using spreading agent (reflecting materials) in all treatments to improve adherence of the spray to the plant foliage for increasing absorption by the plants.

Silicon was added in the form of potassium silicate $\left(\mathrm{K}_{2} \mathrm{SiO}_{3}\right)$, it contains $25 \% \mathrm{~K}$ and $18 \% \mathrm{Si}$, while boron was added as boric acid $17 \%$ boron.

Other agricultural practices for sugar beet field were carried out as recommended by Sugar Crops Research Institute.

\subsection{Recorded data}

\subsubsection{Plant growth}

At harvest time (200 days from sowing ), three plants were randomly taken from each plot to determine plant height $(\mathrm{cm})$ and they were divided separately into different organs; i.e., shoot and root, then they were oven dried at $70{ }^{\circ} \mathrm{C}$ tell constant weight. Dry weight was recorded as shoot and root dry weights/ plant (g). In addition, total plant dry weight/plant (shoot +root) were calculated.

\subsubsection{Photosynthetic Pigments}

Disk samples from the fourth upper leaf were obtained at the beginning sugar storage (130 days from sowing) in both seasons to determine chlorophyll $\mathrm{a}$ and $\mathrm{b}$ as well as carotenoids according to the method described by Wettestein (1957).

\subsubsection{Determination of Potassium, silicon and boron in soil}

Potassium concentration was extracted by $1 \mathrm{M}$ ammonium acetate and determined using flame photometer according to Jackson (1970), While silicon was digested by KOH and boron extracted by hot water in both seasons were determined using Atomic-absorption (Analyst 200, Perkin Elmer, Inc., MA, USA), described by according to the methods Chapman and Pratt (1982).

Plant samples were oven dried $\left(70^{\circ} \mathrm{C}\right)$ and ground thoroughly, wet digested by sulphoric and perchloric acids mixture boron, $\mathrm{Si}$ were measured by atomic absorption and potassium estimated by flame photometer.

\subsubsection{Yield components}

Root yields (ton/fed.) was determined on the whole plot basis,they were harvested, topped and weighed to determine root yield. and relative increases in total root yield than control were recorded. Also yield of top/fed. was recorded, after that, a sample of 10 roots was randomly taken and the following traits were recorded: Root diameter $(\mathrm{cm})$ and average root weight $(\mathrm{g} / \mathrm{plant})$. 


\subsubsection{Root Juice purity Parameters}

All root juice purity parameters were determined at harvest in the Delta Sugar Company, Kafr El-Sheikh, Egypt, according to the following equation:-

Purity $\%=99.36-\{14.27(\mathrm{~V} 1+\mathrm{V} 2+\mathrm{V} 3 / \mathrm{V} 4)\}$

Where: $\mathrm{V} 1=\mathrm{Na}, \mathrm{V} 2=\mathrm{K}, \mathrm{V} 3=\propto-$-amino-N, V4= sucrose $\%$.

Sucrose $\%$ was determined according to the procedure of Le Docte (1927).

2.1.6. Impurity (\%): $\{(\mathrm{K}+\mathrm{Na})$ x 0.0343$)+(\propto-$-amino-N x 0.094$)+0.29\}$

Sugar lost to molasses percentage (SLM \%)

Sucrose losses $\%=0.14(\mathrm{~K}+\mathrm{Na})+0.25(\propto-$ amino- $\mathrm{N})+0.5$

Sugar loss yield $=$ Root yield $\mathrm{x}$ sugar losses $\%$

Sugar yield (fad), which was calculated according to following equation:

Sucrose yield $(\mathrm{fad})=$ Roots yield (fed.) $\mathrm{x}$ Sucrose $\%$.

\subsection{Statistical analysis:}

Statistical analysis was conducted for all collected data. The analysis of variance was calculated according to Snedecor and Cochran (1980), and means separation were done according to Duncan (1958) at 0.05 levels of probability.

\section{Results and Discussion}

\subsection{Plant growth}

\subsubsection{Effect of potassium levels}

Data in Table 2 show that, there were significant differences between all potassium levels ( 0 , 12,18 and $24 \mathrm{kgK}_{2} \mathrm{O} / \mathrm{fad}$.) on plant height $(\mathrm{cm})$ dry weight of shoots, root and total dry weight of sugar beet cv. Oskar poly at 200 days after sowing in both seasons. Increasing potassium levels up to the highest level ( $24 \mathrm{~kg} \mathrm{~K} 2 \mathrm{O} /$ fad. ) significantly increased plant height, dry weight of shoots, root and total dry weight of sugar beet as compared to other levels in both seasons. The increases in total dry weight were about 22.7 and $24.0 \%$ with potassium at $18 \mathrm{~kg} \mathrm{~K} \mathrm{~K}_{2} \mathrm{O} / \mathrm{fad}$. and 28.2 and $28.1 \%$ with potassium at $24 \mathrm{~kg} \mathrm{~K} 2 \mathrm{O} /$ fad. over the control ( untreated with potassium ) in the $1^{\text {st }}$ and $2^{\text {nd }}$ seasons, respectively.

The increase in the root and top fresh and dry weights caused by $\mathrm{K}$ fertilization could be attributed to the stimulating effect of $\mathrm{K}$ on the photosynthesis process in the plants and in turn, the translocation of sugar and carbohydrates assimilates from tops to roots, which lead to increases in the root. Application of $\mathrm{K}$ at the proper rate probably caused higher mobilization of nutrients in soil and plant and translocation of photosynthetic in the plant system and might be enhanced the enzymatic activities which ultimately resulted in higher dry matter accumulation. When plants suffer from K deficiency, translocation of photo assimilated from leaves into actively growing parts of plants is severely reduced leading to reduce growth and development (Hermans et al., 2006).

Table 2 : Effect of potassium levels and Si, B foliar spray treatments on dry weight of parts of sugar beet plant after 200 days from sowing during 2016/2017 and 2017/2018 seasons (Oskar poly)

\begin{tabular}{|c|c|c|c|c|c|c|}
\hline \multirow[t]{2}{*}{ Treatments } & \multicolumn{2}{|c|}{$\begin{array}{l}\text { Plant height } \\
\text { (cm) }\end{array}$} & \multicolumn{2}{|c|}{$\begin{array}{l}\text { Dry weight of } \\
\text { shoots(g/pant) }\end{array}$} & \multicolumn{2}{|c|}{$\begin{array}{c}\text { Dry weight of roots } \\
\text { (g/pant) }\end{array}$} \\
\hline & 2016/2017 & $2017 / 2018$ & $2016 / 2017$ & $2017 / 2018$ & 2016/2017 & $2017 / 2018$ \\
\hline & \multicolumn{6}{|c|}{ Effect of potassium $\left(\mathrm{K}_{2} \mathrm{O}\right)$ levels $(\mathrm{kg} / \mathrm{fad})}$. \\
\hline $\mathbf{0}$ & $31.88 \mathrm{~d}$ & $30.66 \mathrm{c}$ & $21.57 \mathrm{c}$ & $21.91 \mathrm{c}$ & $151.32 \mathrm{~d}$ & $157.09 \mathrm{~d}$ \\
\hline 12 & $34.77 \mathrm{c}$ & $37.11 \mathrm{~b}$ & $23.19 \mathrm{~b}$ & $25.19 \mathrm{~b}$ & $176.17 \mathrm{c}$ & $178.02 \mathrm{c}$ \\
\hline 18 & $37.88 \mathrm{~b}$ & $40.88 \mathrm{a}$ & $24.22 \mathrm{a}$ & $24.92 \mathrm{~b}$ & $187.97 \mathrm{~b}$ & $197.00 \mathrm{~b}$ \\
\hline 24 & $40.44 \mathrm{a}$ & $40.66 \mathrm{a}$ & $24.69 \mathrm{a}$ & $26.85 \mathrm{a}$ & $196.94 \mathrm{a}$ & $202.46 \mathrm{a}$ \\
\hline LSD at 0.05 & 0.77 & 1.10 & 0.80 & 075 & 3.40 & 2.06 \\
\hline \multicolumn{7}{|c|}{ Effect of $\mathrm{Si}$, B foliar spray treatments } \\
\hline Without & $34.16 \mathrm{c}$ & $35.07 \mathrm{c}$ & $20.82 \mathrm{c}$ & $23.13 \mathrm{c}$ & $161.48 \mathrm{c}$ & $169.31 \mathrm{c}$ \\
\hline Silicon & $39.08 \mathrm{a}$ & $39.83 \mathrm{a}$ & $25.55 \mathrm{a}$ & $26.29 \mathrm{a}$ & $191.39 \mathrm{a}$ & $196.58 \mathrm{a}$ \\
\hline Boron & $35.50 \mathrm{~b}$ & $37.08 \mathrm{~b}$ & $23.87 \mathrm{~b}$ & $24.73 \mathrm{~b}$ & $181.42 b$ & $185.04 \mathrm{~b}$ \\
\hline LSD at 0.05 & 0.58 & 0.83 & 0.60 & 0.56 & 2.55 & 1.55 \\
\hline
\end{tabular}


Middle East J. Agric. Res., 10(1): 207-226, 2021

Table 2: Cont.

\begin{tabular}{|c|c|c|c|c|}
\hline \multirow{2}{*}{ Treatments } & \multicolumn{2}{|c|}{ Total dry weight ( g/ plant) } & \multicolumn{2}{|c|}{ Relative increases in total dry weight (\%) } \\
\hline & 2016/2017 & $2017 / 2018$ & 2016/2017 & $2017 / 2018$ \\
\hline & \multicolumn{4}{|c|}{ Effect of potassium $\left(\mathrm{K}_{2} \mathrm{O}\right)$ levels $(\mathrm{kg} / \mathrm{fad})}$. \\
\hline $\mathbf{0}$ & $172.89 \mathrm{~d}$ & $179.01 \mathrm{~d}$ & 00.0 & 00.0 \\
\hline 12 & $199.36 \mathrm{c}$ & $203.22 \mathrm{c}$ & 15.3 & 13.5 \\
\hline 18 & $212.19 \mathrm{~b}$ & $221.92 \mathrm{~b}$ & 22.7 & 24.0 \\
\hline 24 & $221.63 \mathrm{a}$ & $229.31 \mathrm{a}$ & 28.2 & 28.1 \\
\hline LSD at 0.05 & 4.36 & 4.33 & -- & -- \\
\hline & \multicolumn{4}{|c|}{ Effect of $\mathrm{Si}$, B foliar spray treatments } \\
\hline Without & $182.31 \mathrm{c}$ & $192.45 \mathrm{c}$ & 00.0 & 00.0 \\
\hline Silicon & $216.95 \mathrm{a}$ & $222.87 \mathrm{a}$ & 19.0 & 15.8 \\
\hline Boron & $205.30 \mathrm{~b}$ & $209.78 \mathrm{~b}$ & 12.6 & 09.0 \\
\hline LSD at 0.05 level & 3.27 & 3.25 & -- & -- \\
\hline
\end{tabular}

Values having the same alphabetical letter(s) did not significantly differ at the 0.05 level of significance, according to Duncan's multiple range test.

These results are in agreement with those of Fathy et al. (2009), Awad et al. (2013), Mubarak et al. (2016) and Salama et al. (2019) all on sugar beet. They showed that increasing potassium levels recorded the best plant growth.

\subsubsection{Effect of $\mathrm{Si}$, B foliar spray treatments}

Spraying sugar beet plants with silicon (Si) or boron (B) four times at 60, 80, 100 and 120 days after sowing significantly increased plant height dry weight of shoots, root and total dry weight than unsprayed plants at 200 days after sowing in both seasons (Table 2). However, spraying plants with $\mathrm{Si}$ at $200 \mathrm{ppm}$ was the best treatment for increasing plant height dry weight of shoots, root and total dry weight/ plant, followed by spraying with boron at $250 \mathrm{ppm}$ in both seasons. The increases in total dry weight were about 19.0 and $15.8 \%$ for spraying with Si at $200 \mathrm{ppm}$ and 12.6 and $9.0 \%$ for spraying with boron at 250 over unsprayed plants in the $1^{\text {st }}$ and $2^{\text {nd }}$ seasons, respectively.

This result might be due to the role of silicate, which helps in some of the physiological processes of plants reduces biological and non-biological stresses in plants by preserving the potential of plant water, light activity, stomatal conductance and leaves under high levels of transpiration (Das et al., 2017). Results are harmony with Artyszak et al., 2014, Abd El-hady, and Bondok, 2017 and Ibrahim et al. (2017) on sugar beet and Abuzeed et al., 2019 on taro as for silicon effect. Also, Abido (2012), Abd El-Azez (2014) and Dewdar et al. (2015) for boron effect.

\subsubsection{Effect of the interaction}

The interaction between fertilizing with potassium and spraying with Si or B had significant effect on plant height, dry weight of shoots, root and total dry weight of sugar beet at 200 days after sowing in both seasons ( Table 3).

Table 3 : Effect of the interaction between potassium levels and Si, B foliar spray treatments on dry weight of different parts of sugar beet plant after 200 days from sowing during 2016/2017and 2017/2018 seasons

\begin{tabular}{clcccccc}
\hline \multirow{2}{*}{ Treatments } & & \multicolumn{2}{c}{$\begin{array}{c}\text { Plant height } \\
\text { (cm) }\end{array}$} & \multicolumn{2}{c}{$\begin{array}{c}\text { Dry weight of shoots } \\
\text { (g/pant) }\end{array}$} & $\begin{array}{c}\text { Dry weight of roots } \\
\text { (g/pant) }\end{array}$ \\
\hline K2O (kg/fad.) & Si, B & $\mathbf{2 0 1 6 / 2 0 1 7}$ & $\mathbf{2 0 1 7 / 2 0 1 8}$ & $\mathbf{2 0 1 6 / 2 0 1 7}$ & $\mathbf{2 0 1 7 / 2 0 1 8}$ & $\mathbf{2 0 1 6 / 2 0 1 7}$ & $\mathbf{2 0 1 7 / 2 0 1 8}$ \\
\hline \multirow{2}{*}{$\mathbf{0}$} & Without & $29.33 \mathrm{~h}$ & $28.66 \mathrm{~h}$ & $19.21 \mathrm{~g}$ & $19.78 \mathrm{f}$ & $142.46 \mathrm{~g}$ & $146.21 \mathrm{i}$ \\
& Silicon & $36.00 \mathrm{e}$ & $33.33 \mathrm{~g}$ & $22.90 \mathrm{~cd}$ & $24.27 \mathrm{~cd}$ & $160.22 \mathrm{e}$ & $171.71 \mathrm{f}$ \\
& Boron & $30.33 \mathrm{~h}$ & $30.00 \mathrm{~h}$ & $22.61 \mathrm{~d}$ & $21.70 \mathrm{e}$ & $151.28 \mathrm{f}$ & $153.36 \mathrm{~h}$ \\
\hline \multirow{2}{*}{$\mathbf{1 2}$} & Without & $32.33 \mathrm{~g}$ & $34.66 \mathrm{fg}$ & $20.51 \mathrm{f}$ & $23.56 \mathrm{~d}$ & $160.47 \mathrm{e}$ & $165.79 \mathrm{~g}$ \\
& Silicon & $37.33 \mathrm{~d}$ & $38.00 \mathrm{de}$ & $24.93 \mathrm{~b}$ & $26.43 \mathrm{~b}$ & $188.42 \mathrm{c}$ & $192.19 \mathrm{~d}$ \\
& Boron & $34.67 \mathrm{f}$ & $38.67 \mathrm{~d}$ & $24.15 \mathrm{bc}$ & $25.59 \mathrm{~b}$ & $179.61 \mathrm{~d}$ & $176.09 \mathrm{e}$ \\
\hline \multirow{2}{*}{$\mathbf{1 8}$} & Without & $35.66 \mathrm{ef}$ & $36.33 \mathrm{ef}$ & $21.18 \mathrm{ef}$ & $23.41 \mathrm{~d}$ & $161.45 \mathrm{e}$ & $172.46 \mathrm{f}$ \\
& Silicon & $40.67 \mathrm{~b}$ & $44.00 \mathrm{a}$ & $27.59 \mathrm{a}$ & $26.04 \mathrm{~b}$ & $207.05 \mathrm{a}$ & $210.85 \mathrm{a}$ \\
& Boron & $37.33 \mathrm{~d}$ & $42.33 \mathrm{bc}$ & $23.89 \mathrm{bc}$ & $25.32 \mathrm{bc}$ & $195.42 \mathrm{~b}$ & $207.69 \mathrm{~b}$ \\
\hline \multirow{2}{*}{$\mathbf{2 4}$} & Without & $39.33 \mathrm{c}$ & $40.66 \mathrm{c}$ & $22.41 \mathrm{de}$ & $25.79 \mathrm{~b}$ & $181.56 \mathrm{~d}$ & $192.79 \mathrm{~d}$ \\
& Silicon & $42.33 \mathrm{a}$ & $44.00 \mathrm{ab}$ & $26.81 \mathrm{a}$ & $28.42 \mathrm{a}$ & $209.88 \mathrm{a}$ & $211.57 \mathrm{a}$ \\
& Boron & $39.67 \mathrm{bc}$ & $37.33 \mathrm{de}$ & $24.85 \mathrm{~b}$ & $26.34 \mathrm{~b}$ & $199.38 \mathrm{~b}$ & $203.01 \mathrm{c}$ \\
\hline LSD at $\mathbf{0 . 0 5}$ & & $\mathbf{1 . 1 6}$ & $\mathbf{1 . 6 6}$ & $\mathbf{1 . 2 0}$ & $\mathbf{1 . 1 2}$ & $\mathbf{5 . 1 0}$ & $\mathbf{3 . 1 0}$ \\
\hline
\end{tabular}


Table 3: Cont.

\begin{tabular}{clcccc}
\hline \multirow{2}{*}{ Treatments } & & \multicolumn{2}{c}{$\begin{array}{c}\text { Total dry weight } \\
\text { ( g/ plant) }\end{array}$} & $\begin{array}{c}\text { Relative increases in total dry } \\
\text { weight (\%) }\end{array}$ \\
\hline$K_{2} \mathbf{O}$ (kg /fad.) & Si, B & $\mathbf{2 0 1 6 / 2 0 1 7}$ & $\mathbf{2 0 1 7 / 2 0 1 8}$ & $\mathbf{2 0 1 6 / 2 0 1 7}$ & $\mathbf{2 0 1 7 / 2 0 1 8}$ \\
\hline \multirow{2}{*}{$\mathbf{0}$} & Without & $161.67 \mathrm{~g}$ & $165.99 \mathrm{~h}$ & 000 & 000 \\
& Silicon & $183.12 \mathrm{e}$ & $195.98 \mathrm{ef}$ & 13.3 & 18.1 \\
& Boron & $173.89 \mathrm{f}$ & $175.06 \mathrm{~g}$ & 07.6 & 05.5 \\
\hline \multirow{2}{*}{$\mathbf{1 2}$} & Without & $180.98 \mathrm{e}$ & $189.35 \mathrm{f}$ & 11.9 & 14.1 \\
& Silicon & $213.35 \mathrm{c}$ & $218.62 \mathrm{~d}$ & 32.0 & 31.7 \\
& Boron & $203.76 \mathrm{~d}$ & $201.68 \mathrm{e}$ & 26.0 & 21.5 \\
\hline \multirow{2}{*}{$\mathbf{1 8}$} & Without & $182.63 \mathrm{e}$ & $195.87 \mathrm{ef}$ & 13.0 & 18.0 \\
& Silicon & $234.64 \mathrm{a}$ & $236.89 \mathrm{ab}$ & 45.1 & 42.7 \\
& Boron & $219.31 \mathrm{bc}$ & $233.01 \mathrm{bc}$ & 35.7 & 40.4 \\
\hline \multirow{2}{*}{$\mathbf{2 4}$} & Without & $203.97 \mathrm{~d}$ & $218.58 \mathrm{~d}$ & 26.2 & 31.7 \\
& Silicon & $236.69 \mathrm{a}$ & $239.99 \mathrm{a}$ & 46.4 & 44.6 \\
& Boron & $224.23 \mathrm{~b}$ & $229.35 \mathrm{c}$ & 38.7 & 38.2 \\
\hline LSD at $\mathbf{0 . 0 5}$ & & 6.55 & 6.50 & --- & --
\end{tabular}

Values having the same alphabetical letter(s) did not significantly differ at the 0.05 level of significance, according to Duncan's multiple range test.

The interaction between potassium at $24 \mathrm{~kg} \mathrm{~K}_{2} \mathrm{O} /$ fad. and spraying with $\mathrm{Si}$ at $200 \mathrm{ppm}$ gave the highest values of plant height, dry weight of shoots, roots and total dry weight/ plant, without significant differences with the interaction between potassium at $18 \mathrm{~kg} \mathrm{~K}_{2} \mathrm{O} / \mathrm{fed}$. and spraying with $\mathrm{Si}$ at $200 \mathrm{ppm}$ as for plant height in the $2^{\text {nd }}$ seasons and dry weight of shoots in the $1^{\text {st }}$ season, dry weight of roots and total dry weight/ plant in both seasons. The increases in total dry weight were about 46.4 and $44.6 \%$ for the interaction between $24 \mathrm{~kg} \mathrm{~K} 2 \mathrm{O} / \mathrm{fad}$. and spraying with $\mathrm{Si}$ at $200 \mathrm{ppm}, 45.1$ and $42.7 \%$ for the interaction between $18 \mathrm{~kg} \mathrm{~K}_{2} \mathrm{O} / \mathrm{fad}$. and spraying with $\mathrm{Si}$ at $200 \mathrm{ppm}$ over the interaction between 0 $\mathrm{K}_{2} \mathrm{O}$ and unsprayed plant in the $1^{\text {st }}$ and $2^{\text {nd }}$ seasons, respectively. These results are in accordance with those reported by Mubarak et al. (2016) on sugar beet.

\subsection{Photosynthetic pigments}

\subsubsection{Effect of potassium levels}

Fertilizing sugar beet plants with potassium at different levels had significant effect on the concentration of chlorophyll $\mathrm{a}, \mathrm{b}$ and total chlorophyll $(\mathrm{a}+\mathrm{b})$ in leaf tissues at 130 days after sowing in both seasons (Table 4). The concentration of chlorophyll $a, b$ and total chlorophyll $(a+b)$ in leaf tissues significantly increased with potassium up to $24 \mathrm{~kg} \mathrm{~K} \mathrm{~K}_{2} \mathrm{O} / \mathrm{fad}$. in both seasons, with no significant differences with $\mathrm{K}_{2} \mathrm{O}$ at $18 \mathrm{~kg} \mathrm{~K}_{2} \mathrm{O} / \mathrm{fad}$. regarding chlorophyll a in the $1^{\text {st }}$ season. While, the highest concentration of carotenoides in leaf tissues was recorded with $12 \mathrm{~kg} \mathrm{~K}_{2} \mathrm{O} / \mathrm{fad}$. in both seasons. The increases in total chlorophyll in leaf tissues bout 19.9 and $30.7 \%$ for potassium at $18 \mathrm{~kg} \mathrm{~K} 2 \mathrm{O} / \mathrm{fad}$. and 26.7 and $38.0 \%$ for potassium at $24 \mathrm{~kg} \mathrm{~K}_{2} \mathrm{O} /$ fad. over the control ( untreated potassium ) in the $1^{\text {st }}$ and $2^{\text {nd }}$ seasons, respectively.

Role of potassium in photosynthesis and activity of enzymes related to sucrose synthesis and also it's participation in loading the sucrose to phloem are from the most important reasons of increase in sugar's rate and increasing in potassium consumption (Draycott, 2006). Also potassium is an essential nutrient required in higher amounts for plant metabolism especially for photosynthesis and assimilates transport (Wang et al., 2015).

Results agree with Shafeek et al. (2015) on turnip and Mubarak et al. (2016) on sugar beet. They indicated that highest contents of chlorophylls in leaves were obtained with the highest levels of potassium.

\subsubsection{Effect of $\mathrm{Si}, \mathrm{B}$ foliar spray treatments}

Data in Table 4 show that spraying sugar beet plants with Si or B significantly enhancing the concentration of chlorophyll $\mathrm{a}, \mathrm{b}$ and total $(\mathrm{a}+\mathrm{b})$ in leaf tissues compared to unsprayed plants in both seasons. However spraying plants with $\mathrm{Si}$ at $200 \mathrm{ppm}$ recorded the highest values of chlorophyll a, b and total $(\mathrm{a}+\mathrm{b})$ in leaf tissues, while spraying with B at $250 \mathrm{ppm}$ came in the second rank. On the other side, unsprayed plant recorded the maximum values of carotenoides in leaf tissues in both seasons. The 
increases in total chlorophyll $(\mathrm{a}+\mathrm{b})$ in leaf tissues were about 12.7 and $11.4 \%$ for spraying with $\mathrm{Si}$ at $200 \mathrm{ppm}$ and 6.9 and $7.8 \%$ for spraying with $\mathrm{B}$ at $250 \mathrm{ppm}$ over unsprayed plants in the $1^{\text {st }}$ and $2^{\text {nd }}$ seasons, respectively.

Boron is an essential element for photosynthetic pigments, where it increases levels of photosynthetic $\mathrm{O}_{2}$ evolution and $\mathrm{CO}_{2}$ fixation. Moreover, boron decreases the activities of oxidative pentose phosphate enzymes and respiration (Abd El-Hady, 2017).

Results are harmony with those reported by Mubarak et al. (2016) and Abd El-Hady and Bondok (2017) on sugar beet as for silicon effect and El Sayed et al. (2011) on sugar beet as for boron effect.

Table 4 : Effect of potassium levels and $\mathrm{Si}$, B foliar spray treatments on leaf chlorophyll contents (mg /gm FW) after 130 days from sowing of sugar beet during 2016/2017and 2017/2018 seasons

\begin{tabular}{|c|c|c|c|c|c|c|c|c|}
\hline \multirow{3}{*}{ Treatments } & \multicolumn{2}{|c|}{$\begin{array}{l}\text { Chlorophyll } \\
\text { (a) }\end{array}$} & \multicolumn{2}{|c|}{$\begin{array}{l}\text { Chlorophyll } \\
\text { (b) }\end{array}$} & \multicolumn{2}{|c|}{$\begin{array}{l}\text { Total chlorophyll } \\
(\mathbf{a}+\mathbf{b})\end{array}$} & \multicolumn{2}{|c|}{ Carotenoides } \\
\hline & 2016 & 2017 & 2016 & 2017 & 2016 & 2017 & 2016 & 2017 \\
\hline & \multirow{2}{*}{\multicolumn{8}{|c|}{ Effect of potassium levels ( $\mathrm{kg} \mathrm{K}_{2} \mathrm{O} /$ fad.) }} \\
\hline & & & & & & & & \\
\hline $\mathbf{0}$ & $4.48 \mathrm{~b}$ & $4.24 \mathrm{~d}$ & $2.02 \mathrm{~d}$ & $2.08 \mathrm{~d}$ & $6.52 \mathrm{~d}$ & $6.32 \mathrm{~d}$ & $3.18 \mathrm{a}$ & $3.26 \mathrm{a}$ \\
\hline 12 & $4.52 \mathrm{~b}$ & $4.86 \mathrm{c}$ & $2.38 \mathrm{c}$ & $2.38 \mathrm{c}$ & $6.90 \mathrm{c}$ & $7.24 \mathrm{c}$ & $2.94 \mathrm{a}$ & $3.00 \mathrm{a}$ \\
\hline 18 & $5.06 \mathrm{a}$ & $5.46 \mathrm{~b}$ & $2.64 \mathrm{~b}$ & $2.80 \mathrm{~b}$ & $7.82 \mathrm{~b}$ & $8.26 \mathrm{~b}$ & $2.38 \mathrm{~b}$ & $2.56 \mathrm{~b}$ \\
\hline 24 & $5.18 \mathrm{a}$ & $5.6 \mathrm{a}$ & $2.92 \mathrm{a}$ & $3.10 \mathrm{a}$ & $8.26 \mathrm{a}$ & $8.72 \mathrm{a}$ & $2.46 \mathrm{~b}$ & $2.32 \mathrm{~b}$ \\
\hline \multirow[t]{2}{*}{ LSD at 0.05} & 0.24 & 0.08 & 0.08 & 0.06 & 0.28 & 0.26 & 0.28 & 0.26 \\
\hline & \multicolumn{8}{|c|}{ Effect of $\mathrm{Si}$, B foliar spray treatments } \\
\hline Without & $4.54 \mathrm{c}$ & $4.70 \mathrm{c}$ & $2.36 \mathrm{c}$ & $2.48 \mathrm{~b}$ & $6.92 \mathrm{c}$ & $7.18 \mathrm{c}$ & $3.00 \mathrm{a}$ & $3.04 \mathrm{a}$ \\
\hline Silicon & $5.18 \mathrm{a}$ & $5.32 \mathrm{a}$ & $2.62 \mathrm{a}$ & $2.66 \mathrm{a}$ & $7.80 \mathrm{a}$ & $8.00 \mathrm{a}$ & $2.56 \mathrm{~b}$ & $2.64 \mathrm{~b}$ \\
\hline Boron & $4.90 \mathrm{~b}$ & $5.08 \mathrm{~b}$ & $2.48 \mathrm{~b}$ & $2.64 \mathrm{a}$ & $7.40 \mathrm{~b}$ & $7.74 \mathrm{~b}$ & $2.66 \mathrm{~b}$ & $2.70 \mathrm{~b}$ \\
\hline LSD at 0.05 & 0.18 & 0.06 & 0.06 & 0.04 & 0.22 & 0.2 & 0.22 & 0.18 \\
\hline
\end{tabular}

Values having the same alphabetical letter(s) did not significantly differ at the 0.05 level of significance, according to Duncan's multiple range test.

\subsubsection{Effect of the interaction}

The interaction between potassium at $24 \mathrm{~kg} \mathrm{~K} 2 \mathrm{O} /$ fad. and spraying with $\mathrm{Si}$ at $200 \mathrm{ppm}$ recorded significant increases in the concentration of chlorophyll $a, b$ and total $(a+b)$ in leaf tissues of sugar beet at 130 days after sowing, while the interaction between 0 potassium and unsprayed plants recorded the highest values of carotenoides in leaf tissues in both growing seasons. The increases in total chlorophyll in leaf tissues were about 48.5 and $49.8 \%$ for the interaction between $24 \mathrm{~kg} \mathrm{~K}_{2} \mathrm{O} / \mathrm{fad}$. and spraying with $\mathrm{Si}$ at $200 \mathrm{ppm}$ over the interaction between $0 \mathrm{~K}_{2} \mathrm{O}$ and unsprayed plant in the $1^{\text {st }}$ and $2^{\text {nd }}$ seasons, respectively.

Table 5 : Effect of the interaction between potassium levels and $\mathrm{Si}, \mathrm{B}$ foliar spray treatments on leaf chlorophyll contents ( $\mathrm{mg} / \mathrm{gm} \mathrm{DW}$ ) after 130 days from sowing of sugar beet during 2016/2017 and 2017/2018 seasons

\begin{tabular}{|c|c|c|c|c|c|c|c|c|c|}
\hline \multicolumn{2}{|c|}{ Treatments } & \multicolumn{2}{|c|}{$\begin{array}{l}\text { Chlorophyll } \\
\text { (a) } \\
\end{array}$} & \multicolumn{2}{|c|}{$\begin{array}{l}\text { Chlorophyll } \\
\text { (b) }\end{array}$} & \multicolumn{2}{|c|}{$\begin{array}{c}\begin{array}{c}\text { Total chlorophyll } \\
(\mathbf{a}+\mathbf{b})\end{array} \\
\end{array}$} & \multicolumn{2}{|c|}{ Carotenoides } \\
\hline $\begin{array}{l}\text { K } \\
\text { (Kg/fad.) }\end{array}$ & $\mathbf{S i}, \mathbf{B}$ & $\begin{array}{l}2016 \\
/ 2017\end{array}$ & $\begin{array}{l}2017 \\
/ 2018\end{array}$ & $\begin{array}{r}2016 \\
/ 2017\end{array}$ & $\begin{array}{c}2017 \\
/ 2018\end{array}$ & $\begin{array}{r}2016 \\
/ 2017\end{array}$ & $\begin{array}{l}2017 \\
/ 2018\end{array}$ & $\begin{array}{l}2016 \\
/ 2017\end{array}$ & $\begin{array}{c}2017 \\
/ 2018\end{array}$ \\
\hline \multirow{3}{*}{ (12) } & Without & $4.00 \mathrm{~h}$ & $4.2 \mathrm{e}$ & $1.94 \mathrm{~g}$ & $1.90 \mathrm{~h}$ & $5.94 \mathrm{f}$ & $6.1 \mathrm{~h}$ & $3.34 \mathrm{a}$ & $3.4 \mathrm{a}$ \\
\hline & Silicon & $4.22 \mathrm{gh}$ & $4.3 \mathrm{e}$ & $2.12 \mathrm{ef}$ & $2.22 \mathrm{fg}$ & $6.9 \mathrm{e}$ & $6.5 \mathrm{gh}$ & $3.1 \mathrm{ab}$ & $3.22 \mathrm{ab}$ \\
\hline & Boron & $5.06 \mathrm{~b}-\mathrm{e}$ & $4.22 \mathrm{e}$ & $2.04 \mathrm{fg}$ & $2.14 \mathrm{~g}$ & $6.72 \mathrm{e}$ & $6.38 \mathrm{gh}$ & $3.14 \mathrm{ab}$ & $3.2 \mathrm{ab}$ \\
\hline \multirow{3}{*}{12} & Without & 4.92cbe & $4.34 \mathrm{e}$ & $2.24 \mathrm{de}$ & $2.28 \mathrm{f}$ & $6.46 \mathrm{e}$ & $6.62 \mathrm{~g}$ & $3.2 \mathrm{ab}$ & $3.26 \mathrm{a}$ \\
\hline & Silicon & $4.76 \mathrm{ef}$ & $5.24 \mathrm{c}$ & $2.62 b c$ & $2.42 \mathrm{e}$ & $7.48 \mathrm{~d}$ & $7.66 \mathrm{f}$ & $2.9 \mathrm{a}-\mathrm{c}$ & $2.98 \mathrm{ab}$ \\
\hline & Boron & $4.86 \mathrm{~d}-\mathrm{f}$ & $5.02 \mathrm{~d}$ & $2.28 \mathrm{~d}$ & $2.46 \mathrm{e}$ & $6.8 \mathrm{e}$ & $7.48 \mathrm{f}$ & $2.76 \mathrm{~b}-\mathrm{d}$ & $2.8 \mathrm{bc}$ \\
\hline \multirow{3}{*}{18} & Without & $5.32 b$ & $5.06 \mathrm{~d}$ & $2.58 \mathrm{c}$ & $2.76 \mathrm{~d}$ & $7.64 \mathrm{~cd}$ & 7.82ef & $2.56 \mathrm{c}-\mathrm{e}$ & $3.04 \mathrm{ab}$ \\
\hline & Silicon & $5.18 b-d$ & $5.84 \mathrm{a}$ & $2.74 b$ & $2.88 \mathrm{bc}$ & $8.04 b c$ & $8.7 \mathrm{bc}$ & $2.22 \mathrm{ef}$ & $2.34 \mathrm{de}$ \\
\hline & Boron & $4.68 \mathrm{ef}$ & $5.52 \mathrm{~b}$ & $2.64 b c$ & $2.78 \mathrm{~cd}$ & $7.82 \mathrm{~cd}$ & $8.3 \mathrm{~cd}$ & $2.38 \mathrm{~d}-\mathrm{f}$ & $2.34 \mathrm{de}$ \\
\hline \multirow{3}{*}{24} & Without & $4.52 \mathrm{fg}$ & $5.26 \mathrm{c}$ & $2.74 \mathrm{~b}$ & $2.98 b$ & $7.66 \mathrm{~cd}$ & $8.24 \mathrm{de}$ & $2.94 a-c$ & $2.46 \mathrm{~cd}$ \\
\hline & Silicon & $5.78 \mathrm{a}$ & $5.94 \mathrm{a}$ & $3.02 \mathrm{a}$ & $3.18 \mathrm{a}$ & $8.82 \mathrm{a}$ & $9.14 \mathrm{a}$ & $2.04 \mathrm{f}$ & $2.06 \mathrm{e}$ \\
\hline & Boron & $5.26 \mathrm{bc}$ & $5.62 \mathrm{~b}$ & $3.02 \mathrm{a}$ & $3.18 \mathrm{a}$ & $8.3 \mathrm{~b}$ & $8.82 \mathrm{ab}$ & $2.4 \mathrm{~d}-\mathrm{f}$ & $2.46 \mathrm{~cd}$ \\
\hline \multicolumn{2}{|c|}{ LSD at 0.05} & 0.36 & 0.14 & 0.12 & 0.1 & 0.44 & 0.4 & 0.44 & 0.38 \\
\hline
\end{tabular}

Values having the same alphabetical letter(s) did not significantly differ at the 0.05 level of significance, according to Duncan's multiple range test. 


\subsection{Potassium, silicon and boron in shoots}

\subsubsection{Effect of potassium levels}

Potassium, silicon and boron in shoots significantly affected by the increasing of potassium up to the highest level ( $24 \mathrm{~kg} \mathrm{~K}_{2} \mathrm{O} /$ fad.), followed by $\mathrm{K}_{2} \mathrm{O}$ at $18 \mathrm{kgK}_{2} \mathrm{O} /$ fad., while the lowest concentration were recorded with unfertilized plants (control) in both seasons (Table 6). The increases in potassium contents in shoots due to fertilizing with $24 \mathrm{~kg} \mathrm{~K}_{2} \mathrm{O}$ /fed. were about 55.3 and $49.6 \%$ and 52.9 and 55.3 $\%$ for silicon and 32.4 and 27.6 for boron contents over unfertilized plants in the $1^{\text {st }}$ and $2^{\text {nd }}$ seasons, respectively.

These results are in agreement with those of Mubarak et al. (2016). They showed that increasing potassium levels had significantly increased the contents of potassium, silicon and boron in shoots.

\subsubsection{Effect of $\mathrm{Si}$, B foliar spray treatments}

Spraying sugar beet plants with Si or B had significant effect on potassium, silicon and boron in shoots in both seasons (Table 6). The highest values of potassium and silicon contents were recorded by spraying plants with $\mathrm{Si}$ at $200 \mathrm{ppm}$, while spraying with $\mathrm{B}$ at $250 \mathrm{ppm}$ recorded the highest concentrations of boron in shoots in both seasons. Unsprayed plants recorded the lowest values of $\mathrm{K}$, $\mathrm{Si}$ and B in shoots in both seasons. The increases in Potassium contents in shoots due to spraying with Si at 200 ppm were about 7.5 and $9.4 \%$ and 157.4 and $121 . \%$ for silicon contents over unsprayed plants in the $1^{\text {st }}$ and $2^{\text {nd }}$ seasons, respectively. Increases in B contents in shoots due to spraying with B were about 13.7 and $12.5 \%$ over unsprayed plants in the $1^{\text {st }}$ and $2^{\text {nd }}$ seasons, respectively.

This result may be attributed to that the presence of silicon affect the absorption and translocation of several macronutrients (Das et al., 2017).

Table 6: Effect of potassium levels and Si, B foliar spray treatments on potassium, silicon and boron in shoots after 200 days from sowing of sugar beet during 2016/2017 and 2017/2018 seasons

\begin{tabular}{ccccccc}
\hline \multirow{2}{*}{ Treatments } & \multicolumn{2}{c}{ K (\%) } & \multicolumn{2}{c}{ Si ppm } & \multicolumn{2}{c}{ B ppm } \\
\cline { 2 - 7 } & $\mathbf{2 0 1 6 / 2 0 1 7}$ & $\mathbf{2 0 1 7 / 2 0 1 8}$ & $\mathbf{2 0 1 6 / 2 0 1 7}$ & $\mathbf{2 0 1 7 / 2 0 1 8}$ & $\mathbf{2 0 1 6 / 2 0 1 7}$ & $\mathbf{2 0 1 7 / 2 0 1 8}$ \\
\hline $\mathbf{0}$ & $2.35 \mathrm{c}$ & $2.26 \mathrm{~d}$ & $1.02 \mathrm{~d}$ & $1.03 \mathrm{~d}$ & $36.4 \mathrm{c}$ & $38.7 \mathrm{c}$ \\
$\mathbf{1 2}$ & $3.14 \mathrm{~b}$ & $2.95 \mathrm{c}$ & $1.17 \mathrm{c}$ & $1.17 \mathrm{c}$ & $43.8 \mathrm{~b}$ & $44.2 \mathrm{~b}$ \\
$\mathbf{1 8}$ & $3.25 \mathrm{~b}$ & $3.20 \mathrm{~b}$ & $1.38 \mathrm{~b}$ & $1.37 \mathrm{~b}$ & $46.3 \mathrm{ab}$ & $47.5 \mathrm{ab}$ \\
$\mathbf{2 4}$ & $3.65 \mathrm{a}$ & $3.38 \mathrm{a}$ & $1.56 \mathrm{a}$ & $1.60 \mathrm{a}$ & $48.2 \mathrm{a}$ & $49.4 \mathrm{a}$ \\
LSD at 0.05 & 0.13 & 0.10 & 0.06 & 0.08 & 3.70 & 4.10 \\
\hline Without & $2.95 \mathrm{~b}$ & $2.78 \mathrm{~b}$ & $0.68 \mathrm{c}$ & $0.75 \mathrm{c}$ & $41.0 \mathrm{~b}$ & $42.4 \mathrm{~b}$ \\
Silicon & $3.18 \mathrm{a}$ & $3.02 \mathrm{a}$ & $1.75 \mathrm{a}$ & $1.66 \mathrm{a}$ & $43.4 \mathrm{~b}$ & $44.6 \mathrm{~b}$ \\
Boron & $3.17 \mathrm{a}$ & $3.04 \mathrm{a}$ & $1.42 \mathrm{~b}$ & $1.47 \mathrm{~b}$ & $46.6 \mathrm{a}$ & $47.7 \mathrm{a}$ \\
LSD at 0.05 & 0.10 & 0.08 & 0.04 & 0.06 & 2.80 & 3.10 \\
\hline
\end{tabular}

Values having the same alphabetical letter(s) did not significantly differ at the 0.05 level of significance, according to Duncan's multiple range test.

\subsubsection{Effect of the interaction}

Fertilizing sugar beet with potassium and spraying with $\mathrm{Si}$ or $\mathrm{B}$ had significant effect on potassium, silicon and boron in shoots in both seasons (Table 7 and Fig.1).

Table 7: Effect of the interaction between potassium levels and $\mathrm{Si}$, B foliar spray treatments on micronutrients in leaf ( ppm) after 200 days from sowing of sugar beet during 2016/2017 and 2017/2018 seasons

\begin{tabular}{|c|c|c|c|c|c|c|c|}
\hline \multicolumn{2}{|c|}{ Treatments } & \multicolumn{2}{|c|}{ K (\%) } & \multicolumn{2}{|c|}{ Si ppm } & \multicolumn{2}{|c|}{ B ppm in shoots } \\
\hline $\mathrm{K}_{2} \mathrm{O}$ (Kg/fad.) & $\mathrm{Si}, \mathrm{B}$ & $2016 / 2017$ & $2017 / 2018$ & $2016 / 2017$ & $2017 / 2018$ & $2016 / 2017$ & $2017 / 2018$ \\
\hline \multirow{3}{*}{$\mathbf{0}$} & Without & $2.20 \mathrm{~h}$ & $2.22 \mathrm{~d}$ & $0.37 \mathrm{~g}$ & $0.44 \mathrm{~g}$ & $30.7 \mathrm{f}$ & $35.2 \mathrm{f}$ \\
\hline & Silicon & $2.45 \mathrm{~g}$ & $2.25 \mathrm{~d}$ & $1.52 \mathrm{c}$ & $1.40 \mathrm{~d}$ & $37.2 \mathrm{e}$ & 38.4 ef \\
\hline & Boron & $2.42 \mathrm{~g}$ & $2.33 \mathrm{~d}$ & $1.19 \mathrm{e}$ & $1.26 \mathrm{e}$ & $41.3 \mathrm{de}$ & $42.5 \mathrm{c}-\mathrm{e}$ \\
\hline \multirow{3}{*}{12} & Without & $2.94 \mathrm{f}$ & $2.80 \mathrm{c}$ & $0.45 \mathrm{~g}$ & $0.51 \mathrm{~g}$ & $42.6 \mathrm{c}-\mathrm{e}$ & $41.4 \mathrm{~d}-\mathrm{f}$ \\
\hline & Silicon & $3.22 \mathrm{de}$ & $2.96 \mathrm{bc}$ & $1.67 \mathrm{~b}$ & $1.54 \mathrm{c}$ & $43.6 \mathrm{~b}-\mathrm{d}$ & 44.7 b-e \\
\hline & Boron & $3.27 \mathrm{de}$ & $3.11 \mathrm{~b}$ & $1.39 \mathrm{~d}$ & $1.48 \mathrm{~cd}$ & $45.4 \mathrm{a}-\mathrm{d}$ & $46.5 \mathrm{a}-\mathrm{d}$ \\
\hline \multirow{3}{*}{18} & Without & 3.12 ef & $2.80 \mathrm{c}$ & $0.81 \mathrm{f}$ & $0.85 \mathrm{f}$ & $44.5 \mathrm{~b}-\mathrm{d}$ & $45.6 \mathrm{a}-\mathrm{d}$ \\
\hline & Silicon & $3.29 \mathrm{de}$ & $3.43 \mathrm{a}$ & $1.87 \mathrm{a}$ & $1.72 \mathrm{~b}$ & $45.4 \mathrm{a}-\mathrm{d}$ & $46.5 \mathrm{a}-\mathrm{d}$ \\
\hline & Boron & $3.34 \mathrm{~cd}$ & $3.37 \mathrm{a}$ & $1.48 \mathrm{~cd}$ & $1.56 \mathrm{c}$ & $49.2 \mathrm{ab}$ & $50.4 \mathrm{ab}$ \\
\hline \multirow{3}{*}{24} & Without & $3.54 \mathrm{bc}$ & $3.30 \mathrm{a}$ & $1.12 \mathrm{e}$ & $1.23 \mathrm{e}$ & $46.5 \mathrm{a}-\mathrm{d}$ & $47.6 \mathrm{a}-\mathrm{d}$ \\
\hline & Silicon & $3.76 \mathrm{a}$ & $3.46 \mathrm{a}$ & $1.96 \mathrm{a}$ & $1.98 \mathrm{a}$ & $47.7 \mathrm{a}-\mathrm{c}$ & 48.9 a-c \\
\hline & Boron & $3.67 \mathrm{ab}$ & $3.38 \mathrm{a}$ & $1.62 \mathrm{~b}$ & $1.59 \mathrm{bc}$ & $50.5 \mathrm{a}$ & $51.7 \mathrm{a}$ \\
\hline LSD at 0.05 lev & & 0.20 & 0.16 & 0.09 & 0.12 & 5.60 & 6.20 \\
\hline
\end{tabular}

Values having the same alphabetical letter(s) did not significantly differ at the 0.05 level of significance, according to Duncan's multiple range test. 

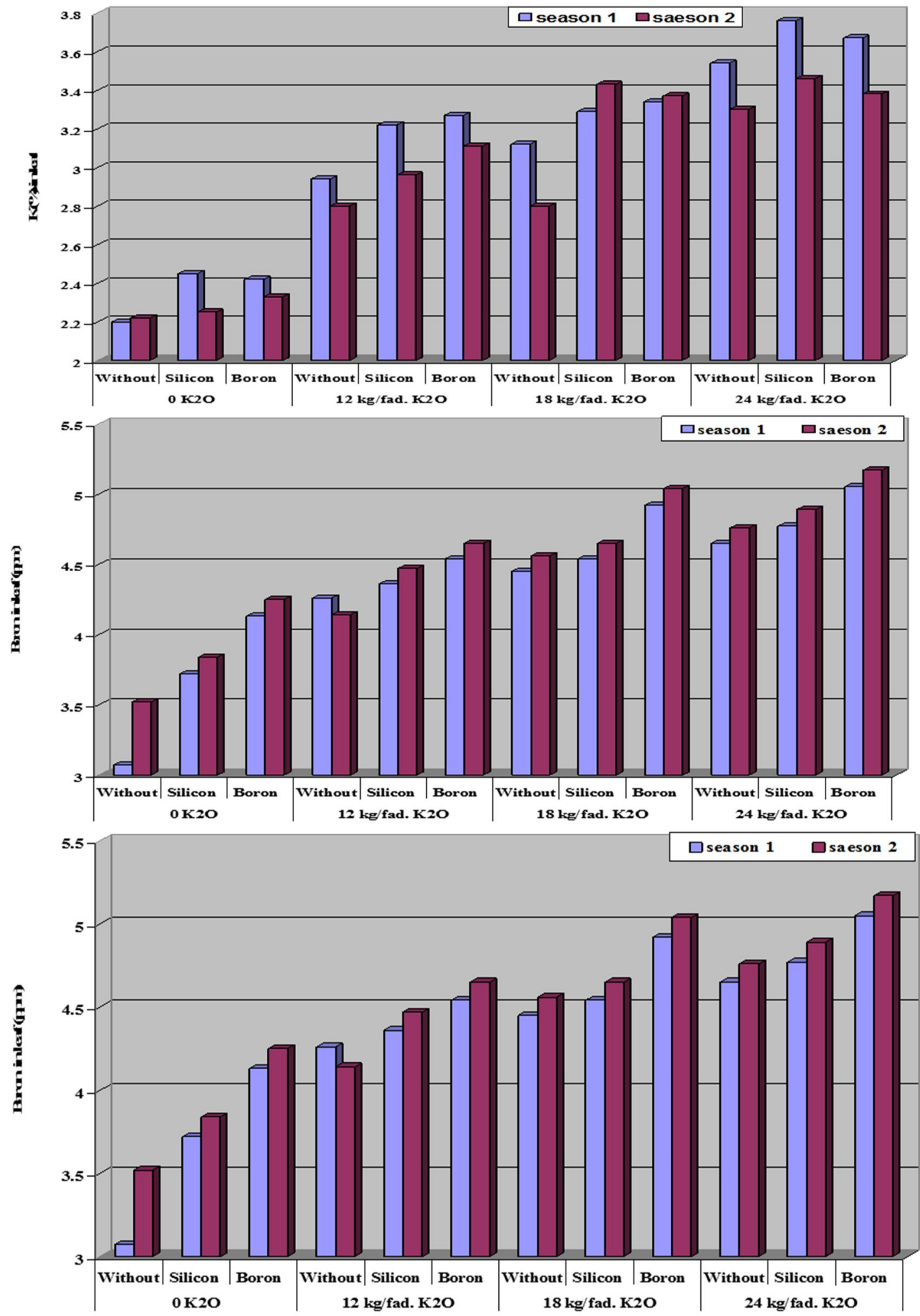

Fig. 1: Effect of the interaction between potassium levels and $\mathrm{Si}, \mathrm{B}$ foliar spray treatments on $\mathrm{K}, \mathrm{Si}$ and B in shoot after 200 days from sowing of sugar beet during 2016/2017 and 2017/2018 seasons

The interaction between potassium at $24 \mathrm{~kg} \mathrm{~K}_{2} \mathrm{O} / \mathrm{fad}$. and spraying with $\mathrm{B}$ at $250 \mathrm{ppm}$ significantly increased boron contents in shoots in both seasons. The interaction between potassium at $24 \mathrm{~kg} \mathrm{~K}_{2} \mathrm{O} /$ fed. and spraying with $\mathrm{Si}$ at $200 \mathrm{ppm}$ was the best interaction treatment for increasing potassium and silicon contents in shoots in both seasons. 


\subsection{Yield and its components}

\subsubsection{Effect of potassium levels}

Data in Table 8 show the effect of potassium as soil application at different levels $(12,18$ and 24 $\mathrm{kg} \mathrm{K}_{2} \mathrm{O}$ /fad.) on yield and its components in both seasons. Fertilizing sugar beet plants grown in clay soil with $24 \mathrm{~K}_{2} \mathrm{O} \mathrm{kg} / \mathrm{fed}$. in the form of potassium sulfate significantly increased root diameter, average root weight yield of top and yield of roots /fad., followed by $\mathrm{K}_{2} \mathrm{O}$ at $18 \mathrm{~kg} / \mathrm{fad}$. in both seasons. The increases in total yield of root were about 73.5 and $71.6 \%$ for potassium at $24 \mathrm{~kg} \mathrm{~K} 2 \mathrm{O} /$ fad. and 61.8 and $61.0 \%$ for potassium at $18 \mathrm{~kg} \mathrm{~K} 2 \mathrm{O} /$ fad. over unfertilized plants with potassium in the $1^{\text {st }}$ and $2^{\text {nd }}$ seasons, respectively.

Potassium plays significant roles in increasing the root elongation, depth, enlarging root absorptive surface, maintaining turgor by reducing water loss and wilting and maximizing water retention in plant tissue, nutrients uptake, phloem unloading, and it enhances the photosynthetic products translocation from the source leaves to the sink organs which subsequently increases the plant dry matter and leads to an increase in the storage root growth (Wang et al., 2013).

The obtained results are in harmony with those reported by Mehrandish et al. (2013) and Attia and AbdelMotagally (2015), Salama et al., (2019) and Aksu and Altay, (2020). They showed that increasing potassium levels to sugar beet plants significantly increased all yield and its components parameters.

\subsubsection{Effect of $\mathrm{Si}, \mathrm{B}$ foliar spray treatments}

There were significant differences between foliar spray treatments (silicon or boron) and unsprayed plants concerning yield and its components in both seasons (Table 8). Spraying sugar beet plants grown in clay soil with $\mathrm{Si}$ at $200 \mathrm{ppm}$ significantly increased root diameter, average root diameter, both yield of top and yield of roots /fad., followed by spraying with B at $250 \mathrm{ppm}$ in both seasons ( Table 8). The increases in total yield of roots were about 15.5 and $10.4 \%$ for spraying with $\mathrm{Si}$ at $200 \mathrm{ppm}, 10.5$ and $5.3 \%$ for spraying with $\mathrm{B}$ at $250 \mathrm{ppm}$ over unsprayed plants in the $1^{\text {st }}$ and $2^{\text {nd }}$ seasons, respectively.

Potassium silicate is origin of high solubility of potassium and silicon is used in the provision of decrease amounts of potassium to facilitate get better the value of the yield (Tarabih et al., 2014). In this concern, the positive effect of the boron element on the top fresh weight of sugar beet could be explained because of its essential role for the activity of enzymes involved in photosynthesis and respiration systems also this element is essential for the formation of new leaves. Moreover it has an active role in translation of assimilation product. Similar results were reported by Abido (2012) who found that the positive effect of boron may be due to the boron role in cell elongation where, in case of boron deficiency, plant leaves were smaller, stiff and thick.

Similar findings were obtained by Artyszak et al. (2014), Ibrahim et al. (2017), Abd El-hady, and Bondok (2017), Ali et al. (2019) and El-Shabrawy and Abd Rabboh,(2020) on sugar beet concerning silicon effect. Abdel-Nasser and Ben-Abdalla, (2019), Rehab et al. (2019), Kandil et al. (2020) and Sarhan et al. 2020) as for boron effect.

Table 8: Effect of potassium levels and $\mathrm{Si}, \mathrm{B}$ foliar spray treatments on yield and its components of sugar beet during 2016/2017 and 2017/2018 seasons

\begin{tabular}{|c|c|c|c|c|c|c|}
\hline \multirow[t]{2}{*}{ Treatments } & \multicolumn{2}{|c|}{$\begin{array}{l}\text { Root diameter } \\
\text { (cm) }\end{array}$} & \multicolumn{2}{|c|}{$\begin{array}{c}\text { Average root weight } \\
(\mathrm{kg})\end{array}$} & \multicolumn{2}{|c|}{$\begin{array}{l}\text { Yield of top } \\
\text { (ton/fad.) }\end{array}$} \\
\hline & 2016/2017 & 2017/2018 & 2016/2017 & $2017 / 2018$ & 2016/2017 & $2017 / 2018$ \\
\hline & \multicolumn{6}{|c|}{ Effect of potassium levels $\left(\mathrm{kg} \mathrm{K}_{2} \mathrm{O} / \mathrm{fad}\right.$.) } \\
\hline $\mathbf{0}$ & $17.21 \mathrm{~d}$ & $16.91 \mathrm{~d}$ & $0.477 \mathrm{~d}$ & $0.474 \mathrm{~d}$ & $5.270 \mathrm{c}$ & $5.128 \mathrm{c}$ \\
\hline 12 & $18.33 \mathrm{c}$ & $18.76 \mathrm{c}$ & $0.549 \mathrm{c}$ & $0.582 \mathrm{c}$ & $5.525 \mathrm{c}$ & $5.450 \mathrm{c}$ \\
\hline 18 & $18.95 \mathrm{~b}$ & $19.80 \mathrm{~b}$ & $0.703 \mathrm{~b}$ & $0.690 \mathrm{~b}$ & $5.974 \mathrm{~b}$ & $6.004 \mathrm{~b}$ \\
\hline 24 & $20.85 \mathrm{a}$ & 20.69 a & $0.785 \mathrm{a}$ & $0.773 \mathrm{a}$ & $6.461 \mathrm{a}$ & $6.609 \mathrm{a}$ \\
\hline \multirow[t]{2}{*}{ LSD at 0.05} & 0.38 & 0.48 & 0.015 & 0.026 & 0.379 & 0.371 \\
\hline & \multicolumn{6}{|c|}{ Effect of $\mathrm{Si}$, B foliar spray treatments } \\
\hline Without & $17.70 \mathrm{c}$ & $18.02 \mathrm{c}$ & $0.572 \mathrm{~b}$ & $0.576 \mathrm{c}$ & $5.494 \mathrm{c}$ & $5.425 \mathrm{~b}$ \\
\hline Silicon & $19.92 \mathrm{a}$ & $20.06 \mathrm{a}$ & $0.660 \mathrm{a}$ & $0.678 \mathrm{a}$ & $6.130 \mathrm{a}$ & $6.055 \mathrm{a}$ \\
\hline Boron & $18.89 \mathrm{~b}$ & $19.04 \mathrm{~b}$ & $0.654 \mathrm{a}$ & $0.635 \mathrm{~b}$ & $5.799 \mathrm{~b}$ & $5.912 \mathrm{a}$ \\
\hline LSD at 0.05 & 0.28 & 0.36 & 0.011 & 0.020 & 0.285 & 0.278 \\
\hline
\end{tabular}


Table 8: Cont.

\begin{tabular}{ccccc}
\hline Treatments & \multicolumn{2}{c}{ Yield of roots (ton/fad.) } & \multicolumn{2}{c}{ Relative increases in total yield than control } \\
\cline { 2 - 4 } & $\mathbf{2 0 1 6 / 2 0 1 7}$ & $\mathbf{2 0 1 7 / 2 0 1 8}$ & $\mathbf{2 0 1 6 / 2 0 1 7}$ & $\mathbf{2 0 1 7 / 2 0 1 8}$ \\
\hline & & Effect of potassium levels (kg K2O/fad.) & 00.0 \\
$\mathbf{0}$ & $12.478 \mathrm{~d}$ & $12.718 \mathrm{~d}$ & .00 .0 & 28.3 \\
$\mathbf{1 2}$ & $16.242 \mathrm{c}$ & $16.317 \mathrm{c}$ & 30.2 & 61.0 \\
$\mathbf{1 8}$ & $20.190 \mathrm{~b}$ & $20.479 \mathrm{~b}$ & 61.8 & 71.6 \\
$\mathbf{2 4}$ & $21.651 \mathrm{a}$ & $21.826 \mathrm{a}$ & 73.5 & -- \\
LSD at $\mathbf{0 . 0 5}$ & 0.806 & 0.781 & -- & 00.0 \\
Without & & Effect of Si, B foliar spray treatments & 10.4 \\
Silicon & $16.233 \mathrm{c}$ & $16.952 \mathrm{c}$ & 00.0 & 05.3 \\
Boron & $18.756 \mathrm{a}$ & $18.707 \mathrm{a}$ & 15.5 & -- \\
\hline
\end{tabular}

Values having the same alphabetical letter(s) did not significantly differ at the 0.05 level of significance, according to Duncan's multiple range test.

\subsubsection{Effect of the interaction}

The interaction between potassium at $24 \mathrm{~kg} \mathrm{~K}_{2} \mathrm{O} / \mathrm{fad}$. and spraying with $\mathrm{Si}$ at $200 \mathrm{ppm}$ significantly increased root diameter, average root weight, yield of top and total yield of roots /fad., followed by The interaction between potassium at $18 \mathrm{~kg} \mathrm{~K}_{2} \mathrm{O} / \mathrm{fad}$. and spraying with $\mathrm{Si}$ at $200 \mathrm{ppm}$ in both seasons (Table 9 and Fig.2). The increases in total yield of roots/fed. were about 95.3 and $88.3 \%$ for the interaction between $24 \mathrm{~kg} \mathrm{~K} 2 \mathrm{O} / \mathrm{fad}$. and spraying with $\mathrm{Si}$ at $200 \mathrm{ppm}, 93.1$ and $83.9 \%$ for the interaction between $24 \mathrm{~kg} \mathrm{~K} 2 \mathrm{O} /$ fad. and spraying with $\mathrm{B}$ at $250 \mathrm{ppm}$ over the plants which received 0 potassium and unsprayed in the $1^{\text {st }}$ and $2^{\text {nd }}$ seasons, respectively.

Table 9: Effect of the interaction between potassium levels and Si, B foliar spray treatments on yield and its components of sugar beet during 2016/2017 and 2017/2018 seasons.

\begin{tabular}{|c|c|c|c|c|c|c|}
\hline \multicolumn{2}{|l|}{ Treatments } & \multirow{2}{*}{$\begin{array}{c}\text { Root } \\
\text { diameter } \\
(\mathrm{cm})\end{array}$} & \multirow{2}{*}{$\begin{array}{l}\text { Average root } \\
\text { weight (kg) }\end{array}$} & \multirow{2}{*}{$\begin{array}{l}\text { Yield of top } \\
\text { (ton/fad.) }\end{array}$} & \multirow{2}{*}{$\begin{array}{c}\text { Yield of } \\
\text { roots } \\
\text { (ton/fad.) }\end{array}$} & \multirow{2}{*}{$\begin{array}{c}\text { Relative } \\
\text { increases in } \\
\text { total yield than } \\
\text { control } \\
\end{array}$} \\
\hline $\mathrm{K}_{2} \mathrm{O}$ (kg/fad.) & $\mathrm{Si}, \mathrm{B}$ & & & & & \\
\hline \multirow{4}{*}{$\mathbf{0}$} & & & & $2016 / 2017$ & & \\
\hline & Without & $16.15 \mathrm{e}$ & $0.403 \mathrm{~g}$ & $4.837 \mathrm{f}$ & $11.511 \mathrm{~g}$ & 00.0 \\
\hline & Silicon & $17.75 \mathrm{~d}$ & $0.547 \mathrm{e}$ & $5.834 \mathrm{~b}-\mathrm{d}$ & $13.502 \mathrm{ef}$ & 17.3 \\
\hline & Boron & $17.73 \mathrm{~d}$ & $0.482 \mathrm{f}$ & $5.141 \mathrm{ef}$ & $12.422 \mathrm{fg}$ & 07.9 \\
\hline \multirow{3}{*}{12} & Without & $17.61 \mathrm{~d}$ & $0.492 \mathrm{f}$ & $5.247 \mathrm{~d}-\mathrm{f}$ & $14.742 \mathrm{e}$ & 28.1 \\
\hline & Silicon & $19.25 \mathrm{c}$ & $0.533 \mathrm{e}$ & $5.682 \mathrm{c}-\mathrm{e}$ & $17.046 \mathrm{~d}$ & 48.1 \\
\hline & Boron & $18.15 \mathrm{~d}$ & $0.623 \mathrm{~d}$ & $5.646 \mathrm{c}-\mathrm{e}$ & $16.938 \mathrm{~d}$ & 47.1 \\
\hline \multirow{3}{*}{18} & Without & $17.69 \mathrm{~d}$ & $0.638 \mathrm{~d}$ & $5.810 \mathrm{~cd}$ & $18.431 \mathrm{c}$ & 60.1 \\
\hline & Silicon & $20.29 \mathrm{~b}$ & $0.750 \mathrm{~b}$ & $6.113 \mathrm{bc}$ & $22.000 \mathrm{a}$ & 91.1 \\
\hline & Boron & $18.89 \mathrm{c}$ & $0.723 \mathrm{c}$ & $6.000 \mathrm{bc}$ & $20.138 \mathrm{~b}$ & 74.9 \\
\hline \multirow{3}{*}{24} & Without & $19.37 \mathrm{c}$ & $0.758 \mathrm{~b}$ & $6.082 \mathrm{bc}$ & $20.246 \mathrm{~b}$ & 75.9 \\
\hline & Silicon & $22.39 \mathrm{a}$ & $0.810 \mathrm{a}$ & $6.892 \mathrm{a}$ & $22.477 \mathrm{a}$ & 95.3 \\
\hline & Boron & $20.79 \mathrm{~b}$ & $0.788 \mathrm{a}$ & $6.410 \mathrm{ab}$ & $22.231 \mathrm{a}$ & 93.1 \\
\hline \multirow[t]{2}{*}{ LSD at 0.05} & & 0.57 & 0.023 & 0.570 & 1.210 & -- \\
\hline & & & & $2017 / 2018$ & & \\
\hline \multirow{3}{*}{$\mathbf{0}$} & Without & $15.45 \mathrm{~g}$ & $0.415 \mathrm{f}$ & $4.644 \mathrm{~d}$ & $11.932 \mathrm{~g}$ & 00.0 \\
\hline & Silicon & $18.33 \mathrm{de}$ & $0.527 \mathrm{~d}$ & $5.625 \mathrm{bc}$ & $13.874 \mathrm{f}$ & 16.3 \\
\hline & Boron & $16.96 \mathrm{f}$ & $0.480 \mathrm{e}$ & $5.116 \mathrm{~cd}$ & $12.348 \mathrm{~g}$ & 03.5 \\
\hline \multirow{3}{*}{12} & Without & $17.69 \mathrm{ef}$ & $0.519 \mathrm{de}$ & $5.138 \mathrm{~cd}$ & $15.615 \mathrm{e}$ & 30.9 \\
\hline & Silicon & $19.87 \mathrm{~b}$ & $0.631 \mathrm{c}$ & $5.728 \mathrm{~b}$ & $17.185 \mathrm{~d}$ & 44.0 \\
\hline & Boron & $18.73 \mathrm{~cd}$ & $0.598 \mathrm{c}$ & $5.484 \mathrm{bc}$ & $16.151 \mathrm{de}$ & 35.4 \\
\hline \multirow{3}{*}{18} & Without & $18.97 \mathrm{~cd}$ & $0.620 \mathrm{c}$ & $5.896 \mathrm{~b}$ & $19.188 \mathrm{c}$ & 60.8 \\
\hline & Silicon & $20.94 \mathrm{a}$ & $0.735 \mathrm{~b}$ & $6.047 \mathrm{~b}$ & $21.308 \mathrm{ab}$ & 78.6 \\
\hline & Boron & $19.49 \mathrm{bc}$ & $0.717 \mathrm{~b}$ & $6.069 \mathrm{~b}$ & $20.942 \mathrm{~b}$ & 75.5 \\
\hline \multirow{3}{*}{24} & Without & $19.99 \mathrm{~b}$ & $0.752 \mathrm{~b}$ & $6.025 \mathrm{~b}$ & $21.074 \mathrm{~b}$ & 76.6 \\
\hline & Silicon & $21.11 \mathrm{a}$ & $0.822 \mathrm{a}$ & $6.821 \mathrm{a}$ & $22.462 \mathrm{a}$ & 88.3 \\
\hline & Boron & $20.99 \mathrm{a}$ & $0.746 \mathrm{~b}$ & $6.981 \mathrm{a}$ & $21.942 \mathrm{ab}$ & 83.9 \\
\hline LSD at 0.05 & & 0.72 & 0.040 & 0.557 & 1.173 & -- \\
\hline
\end{tabular}

Values having the same alphabetical letter(s) did not significantly differ at the 0.05 level of significance, according to Duncan's multiple range test. 

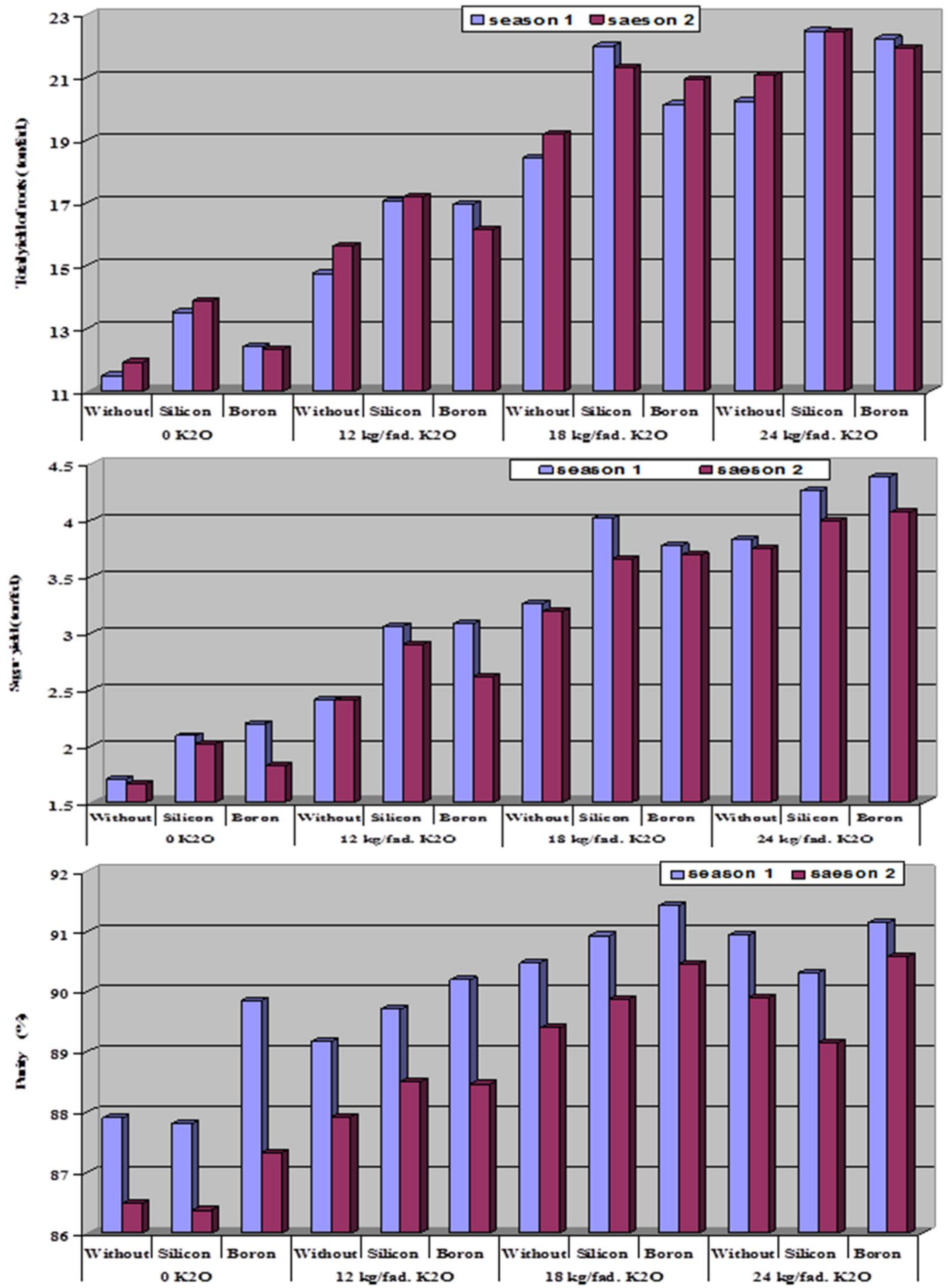

Fig. 2: Effect of the interaction between potassium rates and some foliar spray treatments on total yield of roots /fad. yield of sugars/ fad. and purity (\%) of sugar beat during 2016/2017 and 2017/2018 seasons

\section{5. $\propto$ amino nitrogen, potassium and sodium percentages of sugar beet juice}

\subsection{Effect of potassium levels}

$\propto$ amino nitrogen and sodium percentage in roots were significantly increased with unfertilized plants, while potassium contents in shoots significantly decreased in both seasons ( Table 10). This means that fertilizing sugar beet with $24 \mathrm{~kg} \mathrm{~K}_{2} \mathrm{O} /$ fad. recorded the lowest values of $\propto$ amino nitrogen and sodium percentage and highest values of potassium contents in roots in both seasons.

The favorable effect of potassium fertilizer which improved chemical constituents may be due to the vital role of potassium in building up metabolites and activating starch synthetase enzymes and 
carbohydlevels accumulation which transferred from leaves to developing roots consequently enhanced root and chemical constituents (Nitoses \&, Evans 1969). Similar to those obtained by Neseim, et al. (2014) on sugar beet.

\subsection{Effect of Si, B foliar spray treatments}

Potassium and sodium contents in roots significantly affected by spraying sugar beet plants with silicon or boron, while $\propto$ amino nitrogen did not significantly affected in both seasons (Table 10). Spraying sugar beet plants with $\mathrm{Si}$ at $200 \mathrm{ppm}$ significantly increased potassium contents in roots, without significant differences with $B$ at $250 \mathrm{ppm}$ in the $2^{\text {nd }}$ season. On the other side, sodium contents in shoots significantly increased with unsprayed plants in both seasons.

In this regard, Abbas et al. (2014) found that increasing boron applied as foliar spray recorded the lowest values of $\propto$ amino nitrogen potassium and sodium contents in roots as compared to unsprayed sugar beet plants.

Table 10: Effect of potassium levels and Si, B foliar spray treatments on $\propto$ amino nitrogen, potassium and sodium percentages in root of sugar beet during 2016/2017 and 2017/2018 seasons

\begin{tabular}{|c|c|c|c|c|c|c|}
\hline \multirow[t]{2}{*}{ Treatments } & \multicolumn{2}{|c|}{$\propto \operatorname{amino} \mathbf{N}(\%)$} & \multicolumn{2}{|c|}{ K (\%) } & \multicolumn{2}{|c|}{$\mathrm{Na}(\%)$} \\
\hline & $2016 / 2017$ & $2017 / 2018$ & $2016 / 2017$ & $2017 / 2018$ & $2016 / 2017$ & $2017 / 2018$ \\
\hline & \multicolumn{6}{|c|}{ Effect of potassium levels ( $\mathrm{kg} \mathrm{K}_{2} \mathrm{O} /$ fad.) } \\
\hline $\mathbf{0}$ & $3.81 \mathrm{a}$ & $4.10 \mathrm{a}$ & $4.43 \mathrm{c}$ & $4.60 \mathrm{c}$ & $3.34 \mathrm{a}$ & $3.47 \mathrm{a}$ \\
\hline 12 & $4.04 \mathrm{a}$ & $4.24 \mathrm{a}$ & $5.20 \mathrm{~b}$ & $5.56 \mathrm{~b}$ & $2.60 \mathrm{~b}$ & $2.70 \mathrm{~b}$ \\
\hline 18 & $3.36 \mathrm{~b}$ & $3.53 \mathrm{~b}$ & $5.31 \mathrm{~b}$ & $5.42 \mathrm{~b}$ & $2.60 \mathrm{~b}$ & $2.71 \mathrm{~b}$ \\
\hline 24 & $3.42 \mathrm{~b}$ & $3.46 \mathrm{~b}$ & $5.75 \mathrm{a}$ & $6.03 \mathrm{a}$ & $2.53 \mathrm{~b}$ & $2.64 \mathrm{~b}$ \\
\hline \multirow[t]{2}{*}{ LSD at 0.05} & 0.31 & 0.27 & 0.15 & 0.33 & 0.21 & 0.17 \\
\hline & \multicolumn{6}{|c|}{ Effect of foliar spray treatments } \\
\hline Without & 3.56 & $3.81 \mathrm{a}$ & $4.58 \mathrm{c}$ & $4.84 \mathrm{~b}$ & $3.11 \mathrm{a}$ & $3.24 \mathrm{a}$ \\
\hline Silicon & 3.72 & $3.91 \mathrm{a}$ & $5.61 \mathrm{a}$ & $5.78 \mathrm{a}$ & $2.50 \mathrm{c}$ & $2.60 \mathrm{c}$ \\
\hline Boron & 3.69 & $3.78 \mathrm{a}$ & $5.32 \mathrm{~b}$ & $5.60 \mathrm{a}$ & $2.69 \mathrm{~b}$ & $2.79 \mathrm{~b}$ \\
\hline LSD at 0.05 & NS & NS & 0.11 & 0.24 & 0.13 & 0.11 \\
\hline
\end{tabular}

Values having the same alphabetical letter(s) did not significantly differ at the 0.05 level of significance, according to Duncan's multiple range test.

\subsubsection{Effect of the interaction}

The interaction between potassium level and spraying with silicon or boron had significant effect on $\propto \mathrm{N}, \mathrm{K}$ and $\mathrm{Na}(\%)$ in roots ( Table 11), whereas the interaction between potassium at $12 \mathrm{~kg} \mathrm{~K}_{2} \mathrm{O}$ /fad. and spraying with Si at $200 \mathrm{ppm}$ significantly increased $\propto$ amino nitrogen in both seasons, while the interaction between potassium at $24 \mathrm{~kg} \mathrm{~K}_{2} \mathrm{O} /$ fad. and spraying with $\mathrm{Si}$ at $200 \mathrm{ppm}$ significantly increased potassium contents in shoots in both seasons. on the other hand, unfertilized and unsprayed plants recorded the highest contents on sodium in roots in both seasons.

Table 11: Effect of the interaction treatments between potassium levels and Si, B foliar spray treatments on $\propto$ amino nitrogen, potassium and sodium percentages in root of sugar beet during 2016/2017 and $2017 / 2018$ seasons

\begin{tabular}{clcccccc}
\hline Treatments & \multicolumn{2}{c}{$\propto$ amino N (\%) } & \multicolumn{2}{c}{ K (\%) } & \multicolumn{2}{c}{ Na (\%) } \\
\hline $\mathbf{K}_{\mathbf{2}} \mathbf{O}$ (kg/fad.) & Si, B & $\mathbf{2 0 1 6 / 2 0 1 7}$ & $\mathbf{2 0 1 7 / 2 0 1 8}$ & $\mathbf{2 0 1 6 / 2 0 1 7}$ & $\mathbf{2 0 1 7 / 2 0 1 8}$ & $\mathbf{2 0 1 6 / 2 0 1 7}$ & $\mathbf{2 0 1 7 / 2 0 1 8}$ \\
\hline \multirow{2}{*}{$\mathbf{0}$} & Without & $3.72 \mathrm{a}-\mathrm{c}$ & $4.21 \mathrm{ab}$ & $4.04 \mathrm{~h}$ & $4.07 \mathrm{~g}$ & $3.45 \mathrm{a}$ & $3.59 \mathrm{a}$ \\
& Silicon & $3.93 \mathrm{a}-\mathrm{c}$ & $4.13 \mathrm{a}-\mathrm{c}$ & $4.78 \mathrm{f}$ & $4.65 \mathrm{f}$ & $3.32 \mathrm{ab}$ & $3.45 \mathrm{ab}$ \\
& Boron & $3.78 \mathrm{a}-\mathrm{c}$ & $3.97 \mathrm{a}-\mathrm{d}$ & $4.47 \mathrm{~g}$ & $5.10 \mathrm{~d}-\mathrm{f}$ & $3.25 \mathrm{ab}$ & $3.38 \mathrm{ab}$ \\
\hline \multirow{2}{*}{$\mathbf{1 2}$} & Without & $3.89 \mathrm{a}-\mathrm{c}$ & $4.08 \mathrm{a}-\mathrm{c}$ & $4.68 \mathrm{fg}$ & $5.01 \mathrm{ef}$ & $3.12 \mathrm{ab}$ & $3.24 \mathrm{abc}$ \\
& Silicon & $4.23 \mathrm{a}$ & $4.44 \mathrm{a}$ & $5.57 \mathrm{~cd}$ & $5.96 \mathrm{~b}$ & $2.36 \mathrm{ef}$ & $2.45 \mathrm{ef}$ \\
& Boron & $4.02 \mathrm{ab}$ & $4.22 \mathrm{ab}$ & $5.35 \mathrm{~d}$ & $5.72 \mathrm{bc}$ & $2.33 \mathrm{ef}$ & $2.42 \mathrm{ef}$ \\
\hline \multirow{2}{*}{$\mathbf{1 8}$} & Without & $3.42 \mathrm{bc}$ & $3.59 \mathrm{c}-\mathrm{e}$ & $4.58 \mathrm{fg}$ & $4.90 \mathrm{ef}$ & $3.01 \mathrm{bc}$ & $3.13 \mathrm{bc}$ \\
& Silicon & $3.23 \mathrm{c}$ & $3.39 \mathrm{de}$ & $5.79 \mathrm{bc}$ & $5.77 \mathrm{bc}$ & $2.16 \mathrm{f}$ & $2.25 \mathrm{f}$ \\
& Boron & $3.45 \mathrm{bc}$ & $3.62 \mathrm{~b}-\mathrm{e}$ & $5.58 \mathrm{~cd}$ & $5.61 \mathrm{~b}-\mathrm{d}$ & $2.65 \mathrm{c}-\mathrm{e}$ & $2.76 \mathrm{de}$ \\
\hline \multirow{2}{*}{$\mathbf{2 4}$} & Without & $3.23 \mathrm{c}$ & $3.39 \mathrm{de}$ & $5.03 \mathrm{e}$ & $5.38 \mathrm{cde}$ & $2.89 \mathrm{~b}-\mathrm{d}$ & $3.01 \mathrm{~cd}$ \\
& Silicon & $3.52 \mathrm{a}-\mathrm{c}$ & $3.70 \mathrm{~b}-\mathrm{e}$ & $6.32 \mathrm{a}$ & $6.76 \mathrm{a}$ & $2.19 \mathrm{f}$ & $2.28 \mathrm{f}$ \\
& Boron & $3.53 \mathrm{a}-\mathrm{c}$ & $3.31 \mathrm{e}$ & $5.91 \mathrm{~b}$ & $5.97 \mathrm{~b}$ & $2.53 \mathrm{def}$ & $2.63 \mathrm{e}$ \\
\hline
\end{tabular}

Values having the same alphabetical letter(s) did not significantly differ at the 0.05 level of significance, according to Duncan's multiple range test. 


\subsection{Root quality}

\subsubsection{Effect of potassium levels}

Fertilizing plants with potassium at different levels had significant effect on sucrose contents, juice purity of roots percentage, and yield of sugar/fad. as compared to unfertilized plants in both seasons (Table 12). The application of potassium at $24 \mathrm{~kg} \mathrm{~K}_{2} \mathrm{O} /$ fad. gave the highest values of sucrose contents, juice purity of roots percentage, and yield of sugar/fad., while unfertilized plants gave the highest values of impurity (\%) and sugar lost to molasses percentage in both seasons. The increases in yield of sugar/fad. were about 108.1 and $114.8 \%$ for fertilizing with $24 \mathrm{kgK}_{2} \mathrm{O} /$ fed., 84.4 and $91.6 \%$ for fertilizing with $18 \mathrm{~kg} / \mathrm{fed} . \mathrm{K}_{2} \mathrm{O}$ over unfertilized plants in the $1^{\text {st }}$ and $2^{\text {nd }}$ seasons, respectively.

The results obtained by this study were also similar to those obtained by EL-Shafai (2000),Tawfic and Mostafa (2012) and Neseim et al. (2014), Merwad (2015), Salama et al. (2019) and Aksu and Altay (2020) on sugar beet. All showed that fertilizing plants with potassium recorded the best root quality.

\subsubsection{Effect of Si, B foliar spray treatments}

There were significant differences between foliar spray treatments with silicon and boron as compared to unsprayed plants concerning root quality in both seasons (Table 12). Spraying sugar beet plants with B at $250 \mathrm{ppm}$ gave the highest values of sucrose contents in juice, juice purity and total yield of sugars/fed. and lowest values of impurity (\%) and Sugar lost to molasses (\%) with no significant differences with $\mathrm{Si}$ at $200 \mathrm{ppm}$ concerning sucrose contents in the $2^{\text {nd }}$ season and total yield of sugars /fed. in both seasons. The increases in total yield of sugars /fed. were about 19.8 and $14.3 \%$ for spraying with Si at $200 \mathrm{ppm}, 20.0$ and $10.9 \%$ for spraying with B at $250 \mathrm{ppm}$ over unsprayed in the $1^{\text {st }}$ and $2^{\text {nd }}$ seasons, respectively.

These results were in line with those findings by Ibrahim et al. (2017), Ali et al. (2019), ElShabrawy and Abd Rabboh, (2020) concerning silicon effect. Dewdar et al. (2018), Abdel-Nasser and Ben-Abdalla, (2019), Rehab et al. (2019), Kandil et al. (2020) and Sarhan et al. (2020) regarding boron effect.

Table 12: Effect of potassium levels and some foliar spray treatments on root quality of sugar beet during 2016/2017 and 2017/2018 seasons

\begin{tabular}{|c|c|c|c|c|c|c|c|c|c|c|}
\hline \multirow{2}{*}{$\begin{array}{l}\text { Treatments } \\
\mathrm{K}_{2} \mathrm{O} \\
\text { (kg/fad.) }\end{array}$} & \multicolumn{2}{|c|}{$\begin{array}{l}\text { Sucrose } \\
(\%)\end{array}$} & \multicolumn{2}{|c|}{$\begin{array}{l}\text { Purity } \\
\text { (\%) }\end{array}$} & \multicolumn{2}{|c|}{$\begin{array}{c}\text { Impurity } \\
(\%)\end{array}$} & \multicolumn{2}{|c|}{$\begin{array}{c}\text { Sugar lost to } \\
\text { molasses } \\
\text { percentage \%) }\end{array}$} & \multicolumn{2}{|c|}{$\begin{array}{l}\text { Yield of sugars } \\
\quad \text { (ton/fad.) }\end{array}$} \\
\hline & $\begin{array}{l}2016 \\
/ 2017\end{array}$ & $\begin{array}{l}2017 \\
/ 2018\end{array}$ & $\begin{array}{l}2016 \\
/ 2017\end{array}$ & $\begin{array}{l}2017 \\
/ 2018\end{array}$ & $\begin{array}{l}2016 \\
/ 2017\end{array}$ & $\begin{array}{l}2017 \\
/ 2018\end{array}$ & $\begin{array}{l}2016 \\
/ 2017\end{array}$ & $\begin{array}{r}2017 \\
/ 2018\end{array}$ & $\begin{array}{l}2016 \\
/ 2017\end{array}$ & $\begin{array}{l}2017 \\
/ 2018\end{array}$ \\
\hline & \multicolumn{10}{|c|}{ Effect of potassium levels $\left(\mathrm{kg} \mathrm{K}_{2} \mathrm{O} / \mathrm{fad}\right.$.) } \\
\hline $\mathbf{0}$ & $15.99 \mathrm{~d}$ & $14.41 \mathrm{~d}$ & $88.51 \mathrm{c}$ & $86.73 \mathrm{c}$ & $0.93 \mathrm{a}$ & $0.96 \mathrm{a}$ & $3.48 \mathrm{a}$ & $3.66 \mathrm{a}$ & $1.997 \mathrm{~d}$ & $1.833 \mathrm{~d}$ \\
\hline 12 & $17.51 \mathrm{c}$ & $16.14 \mathrm{c}$ & $89.68 \mathrm{~b}$ & $88.29 \mathrm{~b}$ & $0.93 \mathrm{a}$ & $0.97 \mathrm{a}$ & $3.34 \mathrm{~b}$ & $3.52 \mathrm{a}$ & $2.852 \mathrm{c}$ & $2.638 \mathrm{c}$ \\
\hline 18 & $18.22 \mathrm{~b}$ & $17.13 \mathrm{~b}$ & $90.94 \mathrm{a}$ & $89.90 \mathrm{a}$ & $0.85 \mathrm{~b}$ & $0.88 \mathrm{~b}$ & $3.13 \mathrm{c}$ & $3.30 \mathrm{~b}$ & $3.683 \mathrm{~b}$ & $3.512 \mathrm{~b}$ \\
\hline 24 & $19.18 \mathrm{a}$ & $18.03 \mathrm{a}$ & 90.79 a & $89.87 \mathrm{a}$ & $0.87 \mathrm{~b}$ & $0.91 \mathrm{~b}$ & $3.35 \mathrm{ab}$ & $3.53 \mathrm{a}$ & $4.155 \mathrm{a}$ & $3.937 \mathrm{a}$ \\
\hline LSD at 0.05 & 0.40 & 0.45 & 0.38 & 0.43 & 0.02 & 0.02 & 0.13 & 0.16 & 0.137 & 0.133 \\
\hline & \multicolumn{10}{|c|}{ Effect of $\mathrm{Si}$, B foliar spray treatments } \\
\hline Without & $16.94 \mathrm{c}$ & $15.92 \mathrm{~b}$ & $89.62 \mathrm{~b}$ & $88.42 \mathrm{~b}$ & $0.89 \mathrm{~b}$ & $0.92 \mathrm{~b}$ & $3.32 \mathrm{~b}$ & $3.50 \mathrm{ab}$ & $2.800 \mathrm{~b}$ & $2.749 \mathrm{~b}$ \\
\hline Silicon & $17.65 \mathrm{~b}$ & $16.59 \mathrm{a}$ & $89.68 \mathrm{~b}$ & $88.47 \mathrm{~b}$ & $0.91 \mathrm{a}$ & $0.95 \mathrm{a}$ & $3.43 \mathrm{a}$ & $3.62 \mathrm{a}$ & $3.355 \mathrm{a}$ & $3.143 \mathrm{a}$ \\
\hline Boron & $18.59 \mathrm{a}$ & $16.77 \mathrm{a}$ & $90.65 \mathrm{a}$ & $89.20 \mathrm{a}$ & $0.88 \mathrm{~b}$ & $0.92 \mathrm{~b}$ & $3.22 \mathrm{~b}$ & $3.39 \mathrm{~b}$ & $3.360 \mathrm{a}$ & $3.048 \mathrm{a}$ \\
\hline LSD at 0.05 & 0.30 & 0.34 & 0.28 & 0.32 & 0.01 & 0.02 & 0.10 & 0.12 & 0.102 & 0.100 \\
\hline
\end{tabular}

Values having the same alphabetical letter(s) did not significantly differ at the 0.05 level of significance, according to Duncan's multiple range test.

\subsubsection{Effect of the interaction}

The interaction between potassium at $24 \mathrm{~kg} \mathrm{~K} \mathrm{~K}_{2} \mathrm{O} / \mathrm{fad}$. and spraying with $\mathrm{B}$ at $250 \mathrm{ppm}$ significantly increased sucrose contents in juice of roots, juice purity, total yield of sugars /fed. in both seasons with no significant differences with $\mathrm{Si}$ at $200 \mathrm{ppm}$ as for yield of sugars/fed. in both seasons ( Table 13 and Fig.2). The interaction between potassium levels and foliar spray treatments had no significant effect on impurity (\%) and sugar lost to molasses (\%) in both seasons.

The increases in yield of sugar/fad. were about 149.4 and $140.4 \%$ for the interaction between 24 $\mathrm{kg} \mathrm{K} \mathrm{K}_{2} \mathrm{O} / \mathrm{fad}$. and spraying with $\mathrm{Si}$ at $200 \mathrm{ppm}, 156.9$ and $144.7 \%$ for the interaction between $24 \mathrm{~kg}$ 
$\mathrm{K}_{2} \mathrm{O} /$ fad. and spraying with $\mathrm{B}$ at 250 ppm over the plants which received 0 potassium and unsprayed in the $1^{\text {st }}$ and $2^{\text {nd }}$ seasons, respectively.

The complementally or synergism effect between the enhancement of potassium and boron elements in building up photosynthesis and hence root girth increased accompanied by increasing the width and extend of cambia rings and the volume baranchaima cells that it's store of sugar and reflecting increase in sugar yield/fed. This observation coincide with those found by Christa and Severin (2011).

Table 13: Effect of the interaction treatments between potassium levels and $\mathrm{Si}$, B foliar spray treatments on root quality of sugar beet during 2016/2017 and 2017/2018 seasons

\begin{tabular}{|c|c|c|c|c|c|c|}
\hline \multicolumn{2}{|l|}{ Treatments } & \multirow[b]{2}{*}{ Sucrose (\%) } & \multirow{2}{*}{$\begin{array}{c}\text { Purity } \\
(\%)\end{array}$} & \multirow{2}{*}{$\begin{array}{c}\text { Impurity } \\
(\%)\end{array}$} & \multirow{2}{*}{$\begin{array}{c}\text { Sugar lost to } \\
\text { molasses } \\
\text { percentage } \\
(\%)\end{array}$} & \multirow{2}{*}{$\begin{array}{c}\text { Yield of } \\
\text { sugars } \\
\text { (ton/fad.) }\end{array}$} \\
\hline $\begin{array}{c}\mathrm{K}_{2} \mathrm{O} \\
\text { (kg/fad.) }\end{array}$ & Si, B & & & & & \\
\hline \multirow{3}{*}{$\mathbf{0}$} & Without & $14.83 \mathrm{~g}$ & $87.90 \mathrm{f}$ & 0.92 & 3.45 & $1.707 \mathrm{~g}$ \\
\hline & Silicon & $15.47 \mathrm{f}$ & $87.80 \mathrm{f}$ & 0.95 & 3.61 & $2.089 \mathrm{f}$ \\
\hline & Boron & $17.69 \mathrm{~d}$ & $89.84 \mathrm{~d}$ & 0.92 & 3.40 & $2.197 \mathrm{f}$ \\
\hline \multirow{3}{*}{12} & Without & $16.36 \mathrm{e}$ & $89.16 \mathrm{e}$ & 0.92 & 3.33 & $2.412 \mathrm{e}$ \\
\hline & Silicon & $17.96 \mathrm{~d}$ & $89.70 \mathrm{de}$ & 0.96 & 3.41 & $3.061 \mathrm{~d}$ \\
\hline & Boron & $18.21 \mathrm{~cd}$ & $90.19 \mathrm{~cd}$ & 0.93 & 3.30 & $3.084 \mathrm{~d}$ \\
\hline \multirow{3}{*}{18} & Without & $17.69 \mathrm{~d}$ & $90.48 \mathrm{bc}$ & 0.87 & 3.21 & $3.260 \mathrm{~d}$ \\
\hline & Silicon & $18.25 \mathrm{~cd}$ & $90.93 \mathrm{ab}$ & 0.85 & 3.18 & $4.015 \mathrm{~b}$ \\
\hline & Boron & $18.74 \mathrm{bc}$ & $91.43 \mathrm{a}$ & 0.85 & 3.00 & $3.774 \mathrm{c}$ \\
\hline \multirow{3}{*}{24} & Without & $18.89 \mathrm{~b}$ & $90.94 \mathrm{ab}$ & 0.87 & 3.31 & $3.824 \mathrm{bc}$ \\
\hline & Silicon & $18.94 \mathrm{~b}$ & $90.30 \mathrm{~cd}$ & 0.91 & 3.54 & $4.257 \mathrm{a}$ \\
\hline & Boron & $19.73 \mathrm{a}$ & $91.14 \mathrm{a}$ & 0.85 & 3.21 & $4.386 \mathrm{a}$ \\
\hline \multicolumn{2}{|c|}{ LSD at 0.05 level } & 0.60 & 0.57 & NS & NS & 0.205 \\
\hline \multirow{3}{*}{$\mathbf{0}$} & Without & $13.94 \mathrm{~g}$ & $86.49 \mathrm{~h}$ & 0.95 & 3.63 & $1.663 \mathrm{~h}$ \\
\hline & Silicon & $14.54 \mathrm{fg}$ & $86.38 \mathrm{~h}$ & 0.99 & 3.80 & $2.017 \mathrm{~g}$ \\
\hline & Boron & $14.75 \mathrm{ef}$ & $87.32 \mathrm{~g}$ & 0.95 & 3.57 & $1.821 \mathrm{gh}$ \\
\hline \multirow{3}{*}{12} & Without & $15.38 \mathrm{e}$ & $87.92 \mathrm{fg}$ & 0.96 & 3.50 & $2.402 \mathrm{f}$ \\
\hline & Silicon & $16.88 \mathrm{c}$ & $88.50 \mathrm{ef}$ & 1.00 & 3.59 & $2.901 \mathrm{~d}$ \\
\hline & Boron & $16.18 \mathrm{~d}$ & 88.46 ef & 0.97 & 3.48 & $2.613 \mathrm{e}$ \\
\hline \multirow{3}{*}{18} & Without & $16.63 \mathrm{~cd}$ & $89.39 \mathrm{~cd}$ & 0.90 & 3.38 & $3.191 \mathrm{c}$ \\
\hline & Silicon & $17.16 \mathrm{bc}$ & $89.87 \mathrm{bc}$ & 0.88 & 3.36 & $3.656 \mathrm{~b}$ \\
\hline & Boron & $17.62 \mathrm{~b}$ & $90.46 \mathrm{ab}$ & 0.88 & 3.16 & $3.690 \mathrm{~b}$ \\
\hline \multirow{3}{*}{24} & Without & $17.76 \mathrm{~b}$ & $89.89 \mathrm{bc}$ & 0.90 & 3.49 & $3.743 \mathrm{~b}$ \\
\hline & Silicon & $17.80 \mathrm{~b}$ & $89.15 \mathrm{de}$ & 0.95 & 3.74 & $3.998 \mathrm{a}$ \\
\hline & Boron & $18.55 \mathrm{a}$ & $90.58 \mathrm{a}$ & 0.88 & 3.38 & $4.070 \mathrm{a}$ \\
\hline LSD at 0.05 & & 0.68 & 0.65 & NS & NS & 0.200 \\
\hline
\end{tabular}

Values having the same alphabetical letter(s) did not significantly differ at the 0.05 level of significance, according to Duncan's multiple range test.

\subsection{Some Soil Chemical Characteristics after Harvesting \\ 3.7.1. Effect of potassium levels}

Results in Table 14 indicate that the application of potassium at different levels had significant effect on potassium, silicon and boron in the soil after harvesting of sugar beet in addition the highest values of three minerals were recorded with the plants which fertilized with $24 \mathrm{~kg} / \mathrm{fed} . \mathrm{K}_{2} \mathrm{O}$ ( 467.25 , 7.66 and $0.786 \mathrm{ppm}$ for $\mathrm{K}$, silicon and boron against unfertilized plants ( $232.39,572$ and $0.016 \mathrm{ppm}$ for $\mathrm{K}$, silicon and boron, respectively).

\subsubsection{Effect of $\mathrm{Si}$, B foliar spray treatments}

Available soil potassium, silicon exhibited higher values due to the plants which sprayed with $\mathrm{Si}$ at $200 \mathrm{ppm}(372.50 \mathrm{ppm} \mathrm{K}$ and $6.89 \mathrm{ppm}$ silicon against $308.66 \mathrm{ppm} \mathrm{K}$ and $6.63 \mathrm{ppm}$ silicon, while sprayed plants with $\mathrm{B}$ at $250 \mathrm{ppm}$ recorded $0.448 \mathrm{ppm}$ against $0.300 \mathrm{ppm}$ boron for unsprayed plants (Table 14).

\subsubsection{Effect of the interaction}

Results in Table 14 and Fig.3 indicate that higher available potassium, silicon and boron values under soil amendment of potassium at $24 \mathrm{~kg} \mathrm{~K}_{2} \mathrm{O} / \mathrm{fad}$. and spraying with $\mathrm{Si}$ at $200 \mathrm{ppm}$ significantly 
differed on $\mathrm{K}$ and silicon contents in soil and recorded the highest values (543.09 pm K and $7.67 \mathrm{ppm}$ silicon against $214.80 \mathrm{ppm} \mathrm{K}$ and $5.48 \mathrm{ppm}$ silicon), for 0 potassium and unsprayed plants, while the interaction between the same level of potassium and spraying plants with B at $250 \mathrm{ppm}$ recorded the highest values of boron in the soil after harvesting $(0.970 \mathrm{ppm}$ against $0.011 \mathrm{ppm}$ for 0 potassium and unsprayed plants.

Generally, under the same conditions, it could be concluded that, fertilizing sugar beet plants grown in clay soil with $\mathrm{K}_{2} \mathrm{O}$ at $24 \mathrm{~kg} / \mathrm{fad}$. in the form of potassium sulphate and spraying with $\mathrm{Si}$ at $200 \mathrm{ppm}$ were the best treatment for increasing total yield of roots and $\mathrm{K}_{2} \mathrm{O}$ at $24 \mathrm{~kg} / \mathrm{fad}$. and spraying with boron at $250 \mathrm{ppm}$ gave the best roots quality.

Table 14: Effect of potassium levels and $\mathrm{Si}, \mathrm{B}$ foliar spray treatments and their interaction on some chemical soil properties after harvesting (average two seasons)

\begin{tabular}{|c|c|c|c|c|}
\hline \multirow{2}{*}{\multicolumn{2}{|c|}{ Treatments }} & K ppm & Si ppm & B ppm \\
\hline & & \multicolumn{3}{|c|}{ Effect of potassium levels $\left(\mathrm{kg} \mathrm{K}_{2} \mathrm{O} /\right.$ fad.) } \\
\hline \multicolumn{2}{|c|}{$\mathbf{0}$} & $232.39 \mathrm{~d}$ & $5.72 \mathrm{~d}$ & $0.016 \mathrm{~d}$ \\
\hline \multicolumn{2}{|c|}{12} & $286.44 \mathrm{c}$ & $6.42 \mathrm{c}$ & $0.046 \mathrm{c}$ \\
\hline \multicolumn{2}{|c|}{18} & $367.03 \mathrm{~b}$ & $7.25 \mathrm{~b}$ & $0.646 \mathrm{~b}$ \\
\hline \multirow{2}{*}{\multicolumn{2}{|c|}{ I SD at 005}} & $467.25 \mathrm{a}$ & $7.66 \mathrm{a}$ & $0.786 \mathrm{a}$ \\
\hline & & 11.64 & 0.15 & 0.023 \\
\hline & & \multicolumn{3}{|c|}{ Effect of $\mathrm{Si}$, B foliar spray treatments } \\
\hline \multicolumn{2}{|c|}{ Without } & $308.66 \mathrm{c}$ & $6.63 \mathrm{c}$ & $0.300 \mathrm{c}$ \\
\hline \multicolumn{2}{|c|}{ Silicon } & $372.50 \mathrm{a}$ & $6.89 \mathrm{a}$ & $0.373 \mathrm{~b}$ \\
\hline \multicolumn{2}{|c|}{ Boron } & $333.67 \mathrm{~b}$ & $6.76 \mathrm{~b}$ & $0.448 \mathrm{a}$ \\
\hline \multicolumn{2}{|l|}{ LSD at 0.05} & 8.74 & 0.11 & 0.017 \\
\hline $\mathrm{Kg} \mathrm{K}_{2} \mathrm{O} /$ fad.) & $\mathrm{Si}, \mathrm{B}$ & \multicolumn{3}{|c|}{ Effect of interaction treatments } \\
\hline \multirow{3}{*}{$\mathbf{0}$} & Without & $214.80 \mathrm{j}$ & $5.48 \mathrm{f}$ & 0.0111 \\
\hline & Silicon & $247.19 \mathrm{i}$ & $5.89 \mathrm{e}$ & $0.017 \mathrm{k}$ \\
\hline & Boron & $235.17 \mathrm{i}$ & $5.79 \mathrm{e}$ & $0.022 \mathrm{j}$ \\
\hline \multirow{3}{*}{12} & Without & $269.16 \mathrm{~h}$ & $6.22 \mathrm{~d}$ & $0.032 \mathrm{i}$ \\
\hline & Silicon & $306.69 \mathrm{~g}$ & $6.89 \mathrm{c}$ & $0.046 \mathrm{~h}$ \\
\hline & Boron & $283.46 \mathrm{~h}$ & $6.16 \mathrm{~d}$ & $0.060 \mathrm{~g}$ \\
\hline \multirow{3}{*}{18} & Without & $338.10 \mathrm{f}$ & $7.19 \mathrm{~b}$ & $0.540 \mathrm{f}$ \\
\hline & Silicon & $393.03 \mathrm{~d}$ & $7.13 \mathrm{bc}$ & $0.660 \mathrm{~d}$ \\
\hline & Boron & $369.96 \mathrm{e}$ & $7.44 \mathrm{a}$ & $0.740 \mathrm{c}$ \\
\hline \multirow{3}{*}{24} & Without & $412.56 \mathrm{c}$ & $7.66 \mathrm{a}$ & $0.620 \mathrm{e}$ \\
\hline & Silicon & $543.09 \mathrm{a}$ & $7.67 \mathrm{a}$ & $0.770 \mathrm{~b}$ \\
\hline & Boron & $446.10 \mathrm{~b}$ & $7.66 \mathrm{a}$ & $0.970 \mathrm{a}$ \\
\hline LSD at 0.05 les & & 17.48 & 0.23 & 0.034 \\
\hline
\end{tabular}

Values having the same alphabetical letter(s) did not significantly differ at the 0.05 level of significance, according to Duncan's multiple range test.

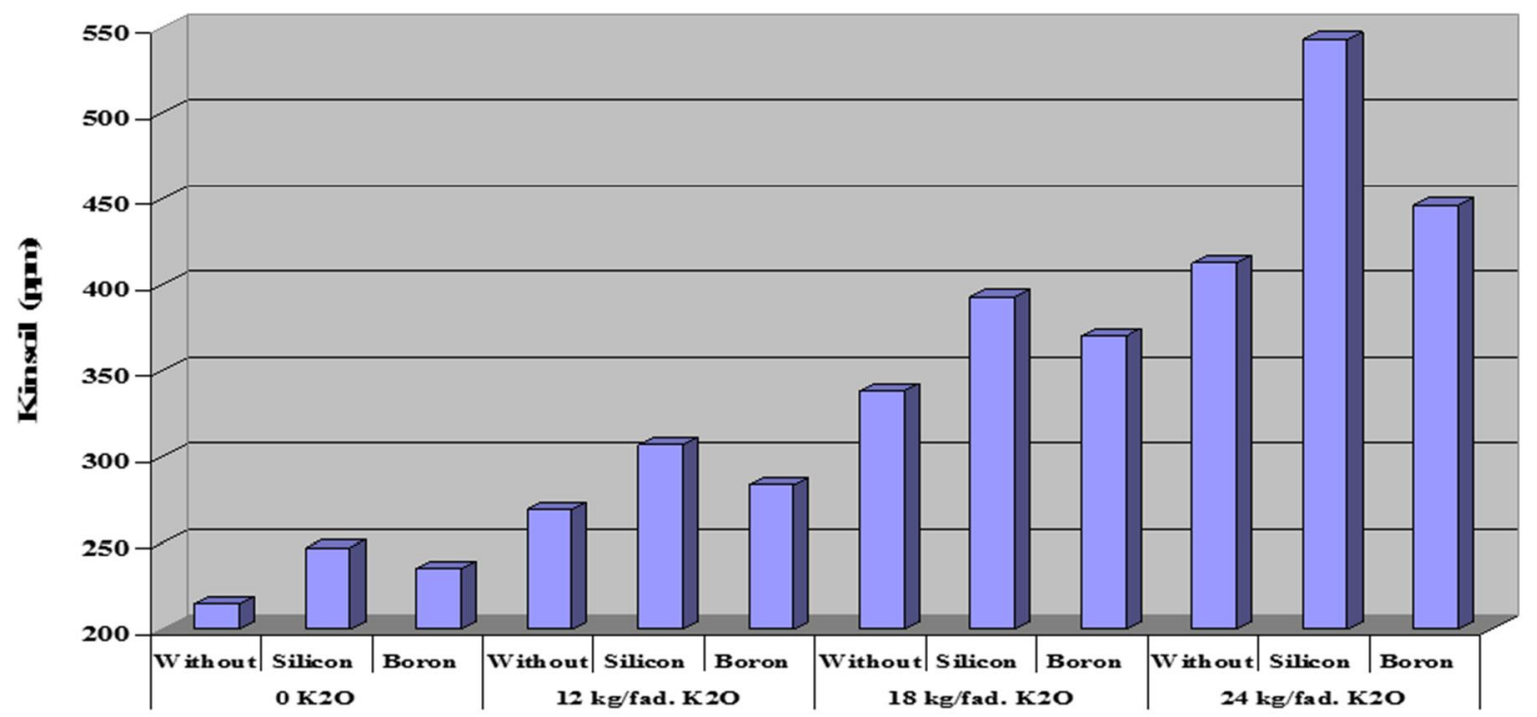



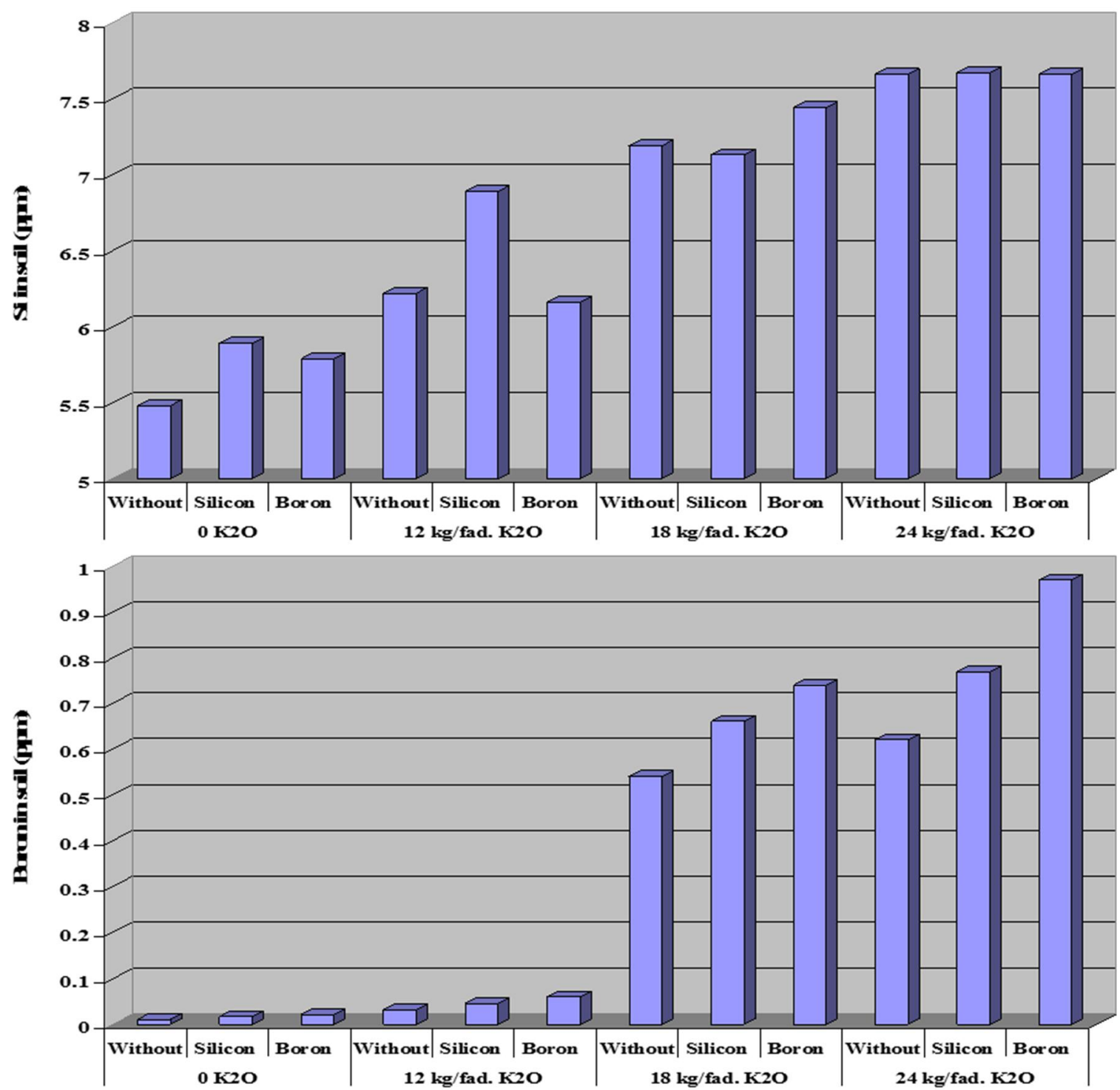

Fig. 3: Effect of the interaction between potassium levels and some foliar spray treatments on $\mathrm{K}, \mathrm{Si}$ and $\mathrm{B}$ in soil after harvesting of sugar beet (average two seasons)

\section{References}

Abbas M.S., M.D.H. Dewdar, E.I. Gaber, and H.A. Abd El-Aleem, 2014. Impact of boron foliar application on quantity and quality traits of sugar beet (Beta vulgaris L.) in Egypt. Res. J. Pharm. Bio. Chem. Sci., 5(5):143-151.

Abd- All A.E., A.E. El-Namas and E.M. EL-Nagga, 2017. Effect of humic acid and foliar application of different potassium sources on yield, quality and water use efficiency of sweet potato grown under drip irrigation in sandy soil. Alex. Sci. Exch. J., 38(3):543-552.

Abd El-Al1, M.M.M., A.M.A. El-Anany and S.M. Rizk, 2019. Rationalization of water consumption for taro plant through the rationing of irrigation and expand the plant ability to resist stress conditions. Inter. J. Plant Soil Sci., 29(4): 1-23.

Abd El-Azez, Y.M., 2014. Effect of yeast extract on sugar beet productivity under different levels of potassium and boron with wastes of sugar factories. Ph.D. Thesis, Fac. Agric., Minia Univ., Egypt.

Abd El-Hady, M.A., 2017. Response of sugar beet growth, productivity and quality to foliar application of different forms of boron microelement and number of sprays under new reclaimed soil conditions. Egypt. J. Agron., 39(3): 401 - 410 
Abd El-hady, M.A. and A.M. Bondok, 2017. Impact of potassium silicate on growth, productivity and powdery mildew disease of sugar beet under newly reclaimed soil conditions. Middle East J. Agric. Res., 6(4): 1232-1242

Abdel-Latif A.A., N.M. Ibrahim and Sh.A. Ismail, 2019. Effect of foliar application of potassium silicate and some postharvest treatments on growth, productivity and storability of garlic. $14^{\text {th }}$ Conf. Agric. Develop. Res., Fac. of Agric., Ain Shams Univ., March, 2019, Cairo, Egypt Special Issue, 27(1): $761-773$.

Abdel-Nasser, G. and Kh.T. Ben-Abdalla, 2019. Boron soil application and deficit irrigation in relation to sugar beet production under drip irrigation system. Int. Res. J. Appl. Sci., 1 (1): 17-29.

Abido, W.A.E., 2012. Sugar beet productivity as affected by foliar spraying with methanol and boron. Int. J. Agric. Sci., 4(7): 287-292.

Abo-Shady, K.A., S.M.M. Hilal, E.M. El-Sheref and M.F.M. Ibraheim, 2010. Yield and quality of sugar beet crop as affected by irrigation intervals, cultivars and potassium fertilization in North Delta. J. Agric. Res., Kafr El-Sheikh Univ., 36(4): 361-376.

Abuzeed, A.M.M., M.E. Ragab, S.A. Abd Elhady and Zahra A.A. El-Sharkawy, 2019. Effect of irrigation levels and foliar spraying with seaweed extract, potassium silicate and abscisic acid on growth, corm yield and quality of taro. Arab Univ. J. Agric. Sci. (AUJAS), Ain Shams Univ., Cairo, Egypt Special Issue, 26(2D): 2275-2285.

Aksu, G. and H. Altay, 2020. The effects of potassium applications on drought stress in sugar beet: Part I. sugar beet quality components. J. Sci. Perspectives, 4(2):157-168.

Ali A.M., S.M. Ibrahim and I.A. Abou-Amer, 2019. Water deficit stress mitigation by foliar application of potassium silicate for sugar beet grown in a saline calcareous soil. Egypt. J. Soil. Sci., 59(1):1523.

Aly, Ehsan F.A., Soha R. Khalil, and Eman M. Abdel Fattah, 2017. Effect of boron, potassium and calcium on growth, yield and quality of two sugar beet varieties under sandy soil conditions. J. Plant Production, 8: 699-704.

Artyszak, A., D. Gozdowski and K. Kucińska, 2014. The effect of foliar fertilization with marine calcite in sugar beet. Plant. Soil Environ., 60:413-417.

Attia, K.K. and, F.M.F. Abdel-Motagally, 2015. Influence of potassium fertilization and foliar application of zinc on sugar beet plants grown on a calcareous sandy soil. Assiut J. Agric. Sci., $46(6): 1-14$.

Awad, N.M.M., H.S. Gharib and Sahr, M.I. Moustafa, 2013. Response of sugar beet (Beta vulgaris L.) to potassium and sulphur supply in clayed soil at north delta, Egypt. Egypt. Agron., 35(1):77-99.

Black, C.A., D.D. Evans., L.E. Ensminger, G.L. White, and F.E. Clark, 1981. "Methods of Soil Analysis”. Part 2. Pp. 1-100. Agron. Inc. Madison. WI., USA.

Cai K., D. Gao, J. Chen, and S. Luo, 2009. Probing the mechanisms of silicon-mediated pathogen resistance. Plant Signaling and Behavior, 4: 1-3.

Camacho-Cristo'bal, J. Juan and A. Gonza'lez-Fontes, 2007. Boron deficiency decreases plasmalemma H?-ATPase expression and nitrate uptake, and promotes ammonium assimilation into asparagine in tobacco roots. Planta, 226: 443-451.

Casey W.H., S.D. Kinrade, C.T.G. Knight, D.W. Rains, and E. Epstein, 2003. Aqueous silicate complexes in wheat, Triticum aestivum L. Plant, Cell and Environ., 27: 51-54.

Chapman, H.D. and P.F. Pratt, 1982. Methods of Plant Analysis, I. Methods of Anaylsis for Soil, Plant and Water. Chapman Publishers, Riverside, California, USA.

Christa M.H. and S.K. Severin, 2011. Growth analysis of autumn and spring sown sugar beet. Europ. J. Agron., 34:1-9.

Cooke, D.A. and R.K. Scott, 1993.The Sugar Beet Crop. Chapman and Hall London, Pp. 262-265.

Das, K.K., G.S. Swamy, D. Biswas and K.K. Chnaniya, 2017. Response of soil application of diatomaceous earth as a source of silicon on leaf nutrient status of guava. Int. J. Curr. Microbiol. App. Sci., 6(4): 1394-1399

Dewdar, M.H.D., M.S. Abbas, E.I. Gaber and H.A. Abd El-Aleem, 2015. Influence of time addition and levels of boron foliar application on growth, quality and yield traits of sugar beet. Int.J.Curr.Microbiol. App. Sci, 4(2): 231-238. 
Dewdar, M.D.H., M.S. Abbas, A.S. El-Hassanin, and H. A.Abd El-Aleem, 2018. Effect of nano micronutrients and nitrogen foliar applications on sugar beet (Beta vulgaris L.) of quantity and quality traits in marginal soils in Egypt. Inter. J. Current Microb. Appl. Sci., 7: 4490-4498.

Draycott, A.P., 2006. "Sugar beet". Blackwell Publishing Ltd, Oxford, UK. 474.

Duncan, B.D., 1958. Multiple range and multiple F. test. Biometric, 11: 1-42.

El Sayed, S.M., R.A. Abo El-Ghait, and K. Aboshady, 2011. Physiological response to foliar application of cobalt and boron on some physiological proprieties, yield and quality of sugar beet. Egypt. J. Appl. Sci. 26(12B): 859-874.

El-Shabrawy E.M. and M.S. Abd Rabboh, 2020. Effect of foliar spraying with micronutrients, elicitors, silicon salts and fertilizers on powdery mildew of sugar beet. Menoufia J. Plant Prot., 5 (October ): $123-141$.

EL-Shafai A.M.A., 2000. Effect of nitrogen and potassium fertilization on yield and quality of sugar beet in Sohag. Egypt. J. Agric. Res., 78(2):759-76.

El-Sherief, M., S. Moustafa, and S. Neana, 2016. Response of sugar beet yield and quality to some micronutrients under sandy soil. J. Soil Sci. Agric. Eng., 7: 97-106.

Enan S.A.A.M., A.M. El-Saady and A.B. El-Sayed, 2016. Impact of foliar feeding with alga extract and boron on yield and quality of sugar beet grown in sandy soil. Egypt. J. Agron., 38(2):319-336.

Fathy, M.F., A. Motagally and K.K. Attia, 2009. Response of sugar beet plants to nitrogen and potassium fertilization in sandy calcareous soil. Int. J. Agric. Biol., 11: 695-700.

Guntzer F., C. Keller, and J.-D. Meunier, 2012. Benefits of plant silicon for crops: A review. Agron. Sustainable Develop., 32: 201-213.

Hamad, A.M., H.M. Sarhan and S.S. Zalat, 2015. Effect of nitrogen, potassium fertilizer and plant distribution patterns on yield and quality of sugar beet (Beta vulgaris L.). J. Plant Production, Mansoura Univ., 6 (4): 517 - 527.

Hermans, C., J.P. Hammond, P.J. White, and N. Verbruggen, 2006. How to plants respond to nutrient shortage by biomass allocation? Trends Plant Sci., 11: 610-617.

Ibrahim, A.M., H.S. Khafaga, A.S. Abd El-Nabi, S.S. Eissa and S.A. Shehata, 2017. Transplanting of sugar beet with soil drench by potassium humate or potassium silicate enhanced plant growth and productivity under saline soil conditions. Current Sci. Inter., 6(2):303-313.

Jackson, M.L., 1970. Soil Chemical Analysis. Prentic Hall, Englewood Ceiffs, N. J.

Kandil, E.E., N.R. Abdelsalam, A.A. Abd EL Aziz, H.M. Ali and M.H. Siddiqui, 2020. Efficacy of nanofertilizer, fulvic acid and boron fertilizer on sugar beet (Beta vulgaris L.) yield and quality. Sugar Tech (Sept-Oct 2020) 22(5):782-791.

Kristek, A., B. Stojic and S. Kristek, 2006. Effect of the foliar boron fertilization on sugar beet root yield and quality. Agricult. Sci. Prof. Rev., 12(1): 1-7.

Le Docte, A., 1927. Commercial determination of sugar beet root using the sachr- Le-Docte process. Sugar J., 29:488-492.

Ma J.F., and N. Yamaji, 2006. Silicon uptake and accumulation in higher plants. Trends in Plant Sci., 11: 392-397.

Mahdi, M., M.J. Moeini and Armin, 2012. Sugar beet (Beta vulgaris L.) response to potassium application under full and deficit irrigation. Euro. J. Exb. Bio., 2(6): 2113-2119.

Masri, M.I., and M. Hamza, 2015. Influence of Foliar Application with Micronutrients on Productivity of Three Sugar Beet Cultivars under Drip Irrigation in Sandy Soils. World J. Agric. Scie., 11 (2): 55-61.

Mehrandish, M., M.M. Moeini and M. Armin, 2013. Sugar beet (Beta vulgaris L.) response to potassium application under full and deficit irrigation. Euro.J. Exp.Bio., 2(6): 2113-2119.

Merwad, A.M.A., 2015. Effect of potassium fertilisation and salicylic acid on yield, quality and nutrient uptake of sugar beet (Beta vulgaris L.) grown in saline soil. Malaysian J. Soil Sci., 19: 95-105

Mubarak, M.U., M. Zahir, S. Ahmad and A. Wakeel, 2016. Sugar beet yield and industrial sugar contents improved by potassium fertilization under scarce and adequate moisture conditions. J. Integrative Agric., 15(11): 2620-2626.

Nemeata Alla, H.E.A., 2017. Effect of boron level and time of application on yield and quality of sugar beet. J. Plant Production, 8: 1071-1075. 
Neseim, M.R., A.Y. Amin and M.M.S. El-Mohamady, 2014. Effect of potassium applied with foliar spray yeast on sugar beet growth and yield under drought stress. Global Advantage Res. J. of Agric. Sci., 3(8): 211-222.

Nitoses, R.E. and H.G. Evans, 1969. Effect of univalent cations on the activity of particulate starch synthase. Plant Physiol., 44: 1260-1266.

Rehab, Ibrahim F., Samia S. El Maghraby, E.E. Kandil, and Nahed Y. Ibrahim, 2019. Productivity and quality of sugar beet in relation to humic acid and boron fertilization under Nubaria conditions. Alex. Sci. Exchange J., 40: 115-126.

Sacała E., 2009. Role of silicon in plant resistance to water stress. J. Elementology, 14: 619-630.

Salama M.A., K.F. Al-Azab and M.E. Hashim, 2019. Response of sugar beet yield and production to different levels from chemical fertilizers and soil salinity. Sylwan 163(5):36-58.

Salami, M. and S. Saadat, 2013. Study of potassium and nitrogen fertilizer levels on the yield of sugar beet in jolge cultivar. J. Appl. Sci., 2(4): 94-100.

Sarhan H.M., M.M. El-Zeny and E.M. Abdel-Fatah, 2020. Effect of foliar spraying times and levels of yeast extract and boron on productivity and quality of sugar beet under sandy soil conditions. Zagazig J. Agric. Res., 47 (2):389-401.

Sayed, S.M., H.M. Abd El-Dayem, S.A. El-Desouky, Z.M. Khedr and M.M. Samy, 2018. Effect of silicon and algae extract foliar application on growth and early yield of globe artichoke plants. $4^{\text {th }}$ Inter. Conf. Biotech. Appl. Agric. (ICBAA), Benha University, Moshtohor and Hurghada, Egypt., 207-214

Sayed, M., and Sarah Omar, 2018. For the most important performance indicators of sugar industry. Faiyum: Fayoum University.

Shafeek M.R., Asmaa R. Mahmoud, Aisha H. Ali, Magda M. Hafez and S.M. Singer, 2015. Effect of different levels of potassium applied with foliar spraying of yeast on growth, yield and root quality of turnip under sandy soil conditions. Int.J. Curr. Microbiol. App. Sci., 4(10): 868-877.

Snedecor, G.W. and W.G. Cochran, 1980. "Statistical Methods". 7th ed. The Iowa State Univ. Press, Ames. Iowa, USA.

Tarabih, M.E., E.E. El-Eryan and M.A. El-Metwally, 2014. Physiological and pathological impacts of potassium silicate on storability of Anna apple fruits. Amer. J. Plant Physio., 9(2): 52-67.

Tawfic S.F. and S.M.I. Mostafa, 2012. Nitrogen and potassium fertiization in relation to qualitative and quantitative traitsof two sugar beet varities. J. Agric. Res. Kafr El-Sheikh Univ., 38(4):489-504.

Wang, M., Q. Zheng, Q. Shen and S. Guo, 2013. The critical role of potassium in plant stress response. Inter. J. Molecular Sci., 14(4): 7370- 7390.

Wang, X.G., ZX. Hua, J.I.J. Hong, L.C. Shan, C.D.W. Qiu, C.Y. Qiu and, Y.H. Yan, 2015. Effects of potassium deficiency on photosynthesis and photoprotection mechanisms in soybean (Glycine $\max ($ L.) Merr.). J. Integrative Agric., 14: 856-863.

Wettstein, D., 1957. Chlorophyll, Letal und der submikro svopische formmech, sallplastiden. Exptl Cell Ser. $12,427-433$.

Yamaji N., N. Mitatni and J.F. Ma, 2008. A transporter regulating silicon distribution in rice shoots. The Plant Cell, 20: 1381-1389. 